\title{
Natural Peptides Inducing Cancer Cell Death: Mechanisms and Properties of Specific Candidates for Cancer Therapeutics
}

\author{
Plinio A. Trinidad-Calderón (D), Carlos Daniel Varela-Chinchilla (D) and Silverio García-Lara *(D) \\ Tecnológico de Monterrey, School of Engineering, and Sciences, Avenida Eugenio Garza Sada 2501, \\ Monterrey 64849, Nuevo León, Mexico; plinio.trinidad@tec.mx (P.A.T.-C.); \\ carlos.varela.ch@gmail.com (C.D.V.-C.) \\ * Correspondence: sgarcialara@tec.mx
}

Citation: Trinidad-Calderón, P.A.; Varela-Chinchilla, C.D.; García-Lara, S. Natural Peptides Inducing Cancer Cell Death: Mechanisms and Properties of Specific Candidates for Cancer Therapeutics. Molecules 2021, 26,7453. https://doi.org/10.3390/ molecules 26247453

Academic Editor: Andrzej Slominski

Received: 18 November 2021

Accepted: 7 December 2021

Published: 9 December 2021

Publisher's Note: MDPI stays neutral with regard to jurisdictional claims in published maps and institutional affiliations.

Copyright: (c) 2021 by the authors. Licensee MDPI, Basel, Switzerland. This article is an open access article distributed under the terms and conditions of the Creative Commons Attribution (CC BY) license (https:// creativecommons.org/licenses/by/ $4.0 /)$.

\begin{abstract}
Nowadays, cancer has become the second highest leading cause of death, and it is expected to continue to affect the population in forthcoming years. Additionally, treatment options will become less accessible to the public as cases continue to grow and disease mechanisms expand. Hence, specific candidates with confirmed anticancer effects are required to develop new drugs. Among the novel therapeutic options, proteins are considered a relevant source, given that they have bioactive peptides encrypted within their sequences. These bioactive peptides, which are molecules consisting of 2-50 amino acids, have specific activities when administered, producing anticancer effects. Current databases report the effects of peptides. However, uncertainty is found when their molecular mechanisms are investigated. Furthermore, analyses addressing their interaction networks or their directly implicated mechanisms are needed to elucidate their effects on cancer cells entirely. Therefore, relevant peptides considered as candidates for cancer therapeutics with specific sequences and known anticancer mechanisms were accurately reviewed. Likewise, those features which turn certain peptides into candidates and the mechanisms by which peptides mediate tumor cell death were highlighted. This information will make robust the knowledge of these candidate peptides with recognized mechanisms and enhance their non-toxic capacity in relation to healthy cells and further avoid cell resistance.
\end{abstract}

Keywords: peptide; cancer; cell; death; therapeutics; mechanism; apoptosis; membrane; model

\section{Introduction}

The development of novel therapeutic agents or strategies targeting cancer has become urgent [1]. Specifically, recent oncological therapeutics have been addressed by multiple approaches [2]. Commonly, surgery, radiation, and systemic treatment, such as chemotherapy and immunotherapy, are combined, among other things [3]. Specifically, newer cancer therapeutics have focused on targeting drug delivery and enhancing selective high cytotoxicity against cancer cells, contrasting with the broad effects of conventional therapy [4].

The recently proposed alternatives are notably represented by hybrid molecules coupled with conventional chemotherapy drugs [5], computer-aided drug discovery [6], and bioactive peptides [7]. Precisely, peptides have shown a trend for performing as therapeutics against cancer cells when obtained from native proteins [8]. Based on this, there are diverse databases, such as CancerPPD [9], SATPdb [10], or THPdb [11], or sequence-based peptide predictors, such as iACP [12] or mACPpred [13], suggesting possible applications and bioactivities of peptides [14]. Nevertheless, even when their effects on cancerous cells are well known, the specific mechanisms by which most peptides act remain undetermined [15].

Therefore, in this review, relevant peptides with a known sequence and specific anticancer mechanisms whose application has reached pathway-level studies and are candidates for anticancer therapeutics were discussed. Moreover, peptides' characteristics 
that make them candidates and the general mechanisms by which cancer cell death is mediated by peptides were presented.

\section{Methodology Used in Literature Research}

Scopus and Google Scholar databases were searched for the keywords anticancer, linear, natural, and peptides. The timespan for literature research was established from 2016 to date. Original and review articles having the specified keywords were included and indistinctly revised for content. Likewise, those articles having the keyword analogs, antibody, antioxidant, conjugate, cyclic, depsipeptide, fraction, nano, proteomic, saccharide, secondary, synthetic, and vaccine were excluded from the analysis of this review.

\section{Properties of Therapeutic Anticancer Peptides}

Recently, peptide definition has come into a debate, with the Food and Drug Administration defining a peptide as any polymer composed of 40 or fewer amino acids [16] and the European Medicines Agency considering them as small molecules if created chemically or as biological entities if extracted from natural sources [17]. Thus, their classification remains contested [18]. Here, peptides were considered molecules consisting of amino acids linked by peptide bonds, ranging from 2 to 50 residues [19].

There are wide varieties of bioactive peptides in nature, and nearly thousands have been discovered [20]. Due to their innovative pharmacological profile and intrinsic properties, peptides represent a match point for novel therapeutics design [21]. The evidence from different studies addressing the structure and activity of both natural and synthetic anticancer peptides claims that various factors are responsible for their potential pharmacological applications [22-24]. Thus, in this section, the most relevant features of peptides that make them candidates for cancer therapeutics are presented.

\subsection{Amino Acid Composition}

Regarding peptide structures, glycine and arginine amino acid residues are prominent in peptides targeting cancer cells [25]. Furthermore, Cys, Gly, Ile, Lys, and Trp are found in various locations of anticancer peptides [26]. Particularly, glycine, because of its structural role ( $\beta$-turns) and cyclization potential, and arginine for its role in cancer therapeutics are crucial elements for the structure and bioactivity of these peptides in toto [27].

Comparatively, arginine, a positively charged basic amino acid [28], has the capacity to enhance the permeability of biological membranes due to the guanidium group found in its side chain [29]. This functional group triggers the interaction between arginine and water or phosphate groups in membrane phospholipids, thus promoting the formation of hydrogen bonds that can destabilize, disrupt, or permeabilize membranes [28,29]. Remarkably, the cell-penetrating efficacy of Arg-rich peptides relies on the number of arginine residues in the peptide sequence [30].

\subsection{Amphipathicity}

Amphipathicity is defined as the ability to survive under hydrophobic and hydrophilic conditions [31]. In this regard, certain peptides have a cationic $\mathrm{NH}_{2}$-terminal forming an amphipathic $\alpha$-helix, which can interact with anionic elements of the cell membrane and is responsible for mediating cytotoxic effects with cancer cells [32]. Moreover, these $\alpha$-helical peptides share the characteristic that they possess an amphipathic conformation with the nonpolar and polar face in a hydrophobic environment [33].

\subsection{Hydrophobicity}

Anticancer peptides have known requirements for their activity, including being moderately hydrophobic [34], the molecular feature of being repelled by water [35]. Specifically, the hydrophobic content of anticancer peptides is about $30 \%$ but can be higher in some cases [36]. Moreover, hydrophobic amino acids are found in positions from 45-225 , and polar amino acids are found in the other helix face [37]. Particularly, hydrophobicity has 
been observed to influence the bioavailability and transport of bioactive peptides [38]. Likewise, most $\alpha$-helical anticancer peptides have a range of $40-60 \%$ hydrophobic amino acids in their composition [37].

\subsection{Net Charge}

Anticancer peptides have been shown to be generally cationic when found in neutral $\mathrm{pH}$, with their charge varying from +2 to +9 [36]. Respectively, many studies have indicated that a greater positive net charge increases peptide potency and variably affects cell selectivity [37]. Specifically, the overall positive net charge is given by arginine and lysine amino acid residues [36]. Additionally, the net charge affects peptide bioavailability as carrier transport have a higher affinity for neutral peptides, whereas paracellular transport preferentially transports oligopeptides with net negative charge [38]. Furthermore, peptides with charged functional groups have reduced intestinal absorption at different sites, resulting in reduced bioavailability [11].

\subsection{Secondary Structure in Membrane}

This particular feature refers to recurrent arrangements in the space of sequential amino acid residues along a peptide chain [39]. The largest recognized group of secondary structures in anticancer peptides is the $\alpha$-helical (approximately 30\%) [37]. Although this secondary structure is the most common, peptides may also adopt a $\beta$-sheet or a linear structure [36]. Correspondingly, the secondary structure is generally inducible by the interaction with a lipid bilayer or a water mixture, showing that peptides have adaptive conformations related to their anticancer and antimicrobial properties [37].

\subsection{Spatial Structure}

Peptides with specific spatial conformations have shown higher activity than linear chemically synthesized peptides [40]. Interestingly, those peptides with an $\alpha$-helical structure may have clear hydrophilic and hydrophobic surfaces or have a concentration of amino acids in the N-terminal and C-terminal to have distinct hydrophilic and hydrophobic sides, both of which allow binding and interactions with the lipid membrane [20]. Moreover, it has been observed that peptide stability may depend on its structural conformation [40]. Specifically, studies have argued that the $\alpha$-helical structure has a more stable structure and is responsible for most of the anticancer activity of some peptides [20].

\subsection{Oligomerization Ability}

Oligomerization is a fundamental feature of peptides [41] related to their structure and function and influences their binding affinity [42]. As previously mentioned, peptides usually have a hydrophobic C-terminal that has been proposed as the facilitator for peptide entry into cells; thus, enabling oligomerization and successively pore formation and cell death [32]. Furthermore, studies have shown that dimeric and tetrameric peptides display a higher cytotoxic effect on cancer cells [43], proposing that oligomerization improves anticancer activity [44].

\section{Characteristics of Cancerous Cells Making Them Susceptible to Peptides}

Peptides targeting cancer cells are of prominent interest [45], mainly because they bind in a non-specific manner to negatively charged structures, which are both exclusively and homogenously displayed by cancer cells $[46,47]$. Such targets are mainly represented by phospholipids, such as phosphatidylserine (PS), which are secluded in the inner side of the plasmatic membrane in normal cells, allowing to increase specificity $[47,48]$.

Additional characteristics, such as cholesterol content and presence of microvilli on cancer cell surface, allow to enhance susceptibility to peptides and promote selective cytotoxicity as well [49]. Therefore, this section elaborates on the significant role of these cell features. 


\subsection{Negative Charge}

Nowadays, different studies still claim that cancer cells possess a negatively charged cell surface [45]. Specifically, the negative charge of cell surface mainly derives from (1) overexpression of PS (9\%), (2) proteoglycans side chains in the form of heparin sulfate, (3) presence of repeated regions of O-glycosylation on membrane mucines, and (4) high levels of phosphatidylethanolamine $[50,51]$.

Remarkably, high levels of ROS and hypoxia, both modifying factors of tumor microenvironment, are able to induce dysregulation in membrane phospholipids [52]. Hence, cancer cells tend to lose their asymmetric phospholipid distribution between layers of plasmatic membrane and, thus, expose PS outside [53].

\subsection{Cholesterol Content}

The fluidity and stiffness of cancer cells usually get affected when peptides are internalized into the hydrophobic layer of plasmatic membranes which, consequently, favor cell lysis [54]. Thus, further research remains needed to accurately determine the role of plasmatic membrane fluidity, mainly because the high levels of membranal cholesterol in lipid rafts can reduce the lytic action of peptides toward cancer cells [45,55].

Until now, cancer cell membranes, e.g., those from leukemia and lung cancer cells, are frequently more fluidic than those from healthy cells because of a lower cholesterol level [56]. Counterintuitively, a reversed trend has been observed in breast and prostate cancer cells [45].

\subsection{Microvilli}

A high number of microvilli both enhances surface contact area and increases the attraction of peptides to cancer cells [50,57], in contrast to healthy cell membranes [58]. Further, the irregular shape and varied size of microvilli are reported to alter cell adhesion, extracellular communication with the microenvironment, and the receptor accessibility of cancer cells in response to the exposition to cationic macromolecules, e.g., peptides [45].

\section{Cell Death of Cancerous Cells Mediated by Peptides}

Anticancer peptides can display effects such as cell death against cancer cells [11]. Accordingly, the different time dependence of cell death induction by peptides indicates the existence of other mechanisms [59] that also seem to depend on the presence of anionic lipids [60]. In this section, the general mechanisms by which peptides perform cell death are comprehensively described as follows: (1) membrane interaction causing disruption or micellization of the cytoplasmic membrane through pore formation [41], (2) necrosis, and (3) apoptosis induction through membrane interactions [61] or entering the cell to reach a mitochondrial target [60].

\subsection{Disruption of Cell Membrane}

Pore-forming proteins are characterized by being water-soluble and able to insert themselves into lipid bilayers [62]. Specifically, different interactions of peptides with the lipid membrane of cancer cells have been documented as the secondary structure of peptides allows them to interact with the negatively charged membrane of neoplastic cells [37].

\subsubsection{Transient Pore Formation}

Pore formation by peptides can be found naturally in bacterial toxin function, viral infection, apoptosis, and innate immunity, hence performing in medical applications [63,64]. Transient pores occur due to membrane leaking immediately after the exposition to peptides, with most leakage happening during this time, rapidly slowing afterward, and eventually attaining a plateau with incomplete leakage [65]. 


\subsubsection{Membrane Disruption}

This phenomenon refers to membrane destabilization through several modes of lysis, which may include pore formation, lipid disorganization, or mechanical stress [66,67]. Frequently cited models describing this interaction are the barrel-stave pore, toroidal pore, carpet, and the detergent-like and unifying Shai-Huang-Matsuzaki models [37,68,69].

The most recognized models for pore structure are the barrel-stave pores, defined as a cylindrical pore lined by peptides, and the toroidal pore, where two membrane leaflets bend and join themselves [63]. Regarding toroidal pores, these pores can change dynamically, demonstrating a multilevel signal when measuring a transmembrane current [70].

\subsection{Necrosis and Apoptosis}

Currently, the classification of programmed cell death includes 11 cell death mechanisms, with apoptosis among them [71]. Necrosis is excluded from such classification because of its unregulated nature, although recent scientific evidence claims that necrosis can be well controlled in certain cases [72].

\subsubsection{Necrosis}

Necrosis is an uncontrolled form of cell death induced by an external stimulus, such as inflammation or hypoxia [73]. This results in the expansion of organelles, plasma membrane fracture, and inflammatory responses induced by the leakage of intracellular contents [74]. Nevertheless, it involves different pro-inflammatory molecules, such as the dimeric nuclear factor- $\mathrm{kB}$ (NF- $\mathrm{kB}$ ), a transcription factor [75]. Specifically, necrosis occurs in other forms [76,77]. Nevertheless, apoptosis can culminate in secondary necrosis in the absence of ATP [78].

\subsubsection{Apoptosis}

Apoptosis is when cells cease to grow and multiply and enter a process mediated by cysteine proteases known as caspases [79] that ends in controlled death without spillage of its contents [73]. Generally, apoptosis can be initiated by intrinsic and extrinsic pathways [80], both described below. Specifically, it can be initiated through tumor necrosis factor (TNF) receptor type-1 [81] associated death domain (TRADD) [82], Fas-associated death domain (FADD) [83], and procaspase $8[84,85]$.

\section{Extrinsic Pathway}

The extrinsic pathway of apoptosis is activated by the binding of TNF and the fibroblast-associated surface ligand (FasL) to the cell membrane's death receptors [86], activating the death-induced signaling complex which, in turn, activates caspase-8 [87]. Specifically, Fas, a membrane-bound receptor that is part of the TNF superfamily, actuates the extrinsic apoptotic pathway through the crosslinking of FasL [88]. Moreover, procaspase- 8 cleaves into caspase- 8 and activates itself in an initiatory complex, thus inducing the extrinsic apoptotic pathway [84].

\section{Intrinsic Pathway}

The intrinsic pathway of apoptosis is controlled by the B-cell lymphoma-2 (Bcl-2) protein family [78]. This protein family divides into three subfamilies: anti-apoptotic, $\mathrm{BH}-$ 3-only (proapoptotic), and pore-forming proteins ("executioners"; proapoptotic) [89]. Bax and Bak are proapoptotic proteins promoting the permeabilization of mitochondrial outer membrane [90]. Particularly, Bax/Bak insert themselves into the mitochondrial membrane, causing the subsequent release of cytochrome $\mathrm{c}$ into the cytosol, consequently combining with the oligomerization of the apoptotic protease activating factor-1 (Apaf-1) to create the apoptosome and, thus, activating caspase-9 [91,92]. 


\section{Specific Candidate Peptides as Anticancer Therapeutics}

Although cancer therapeutics have recently evolved, the evolution of cancer-site specific targeting peptides is still stagnant as the clinical field still awaits a molecule with the capacity of targeting a variety of cancers [93]. In this regard, many years have passed since the first anticancer peptide was found cytotoxic for various cell lines: magainin, from Xenopus laevis [94].

This section discusses peptides having a known sequence and a specific recognized mechanism for inducing cancer cell death. Moreover, they are sorted in an arrangement of membrane damage and apoptotic cell death mechanisms. Correspondingly, their stateof-the-art, specific amino acid sequence (Tables 1 and 2) and 3D models (Figures 1 and 2) are presented.

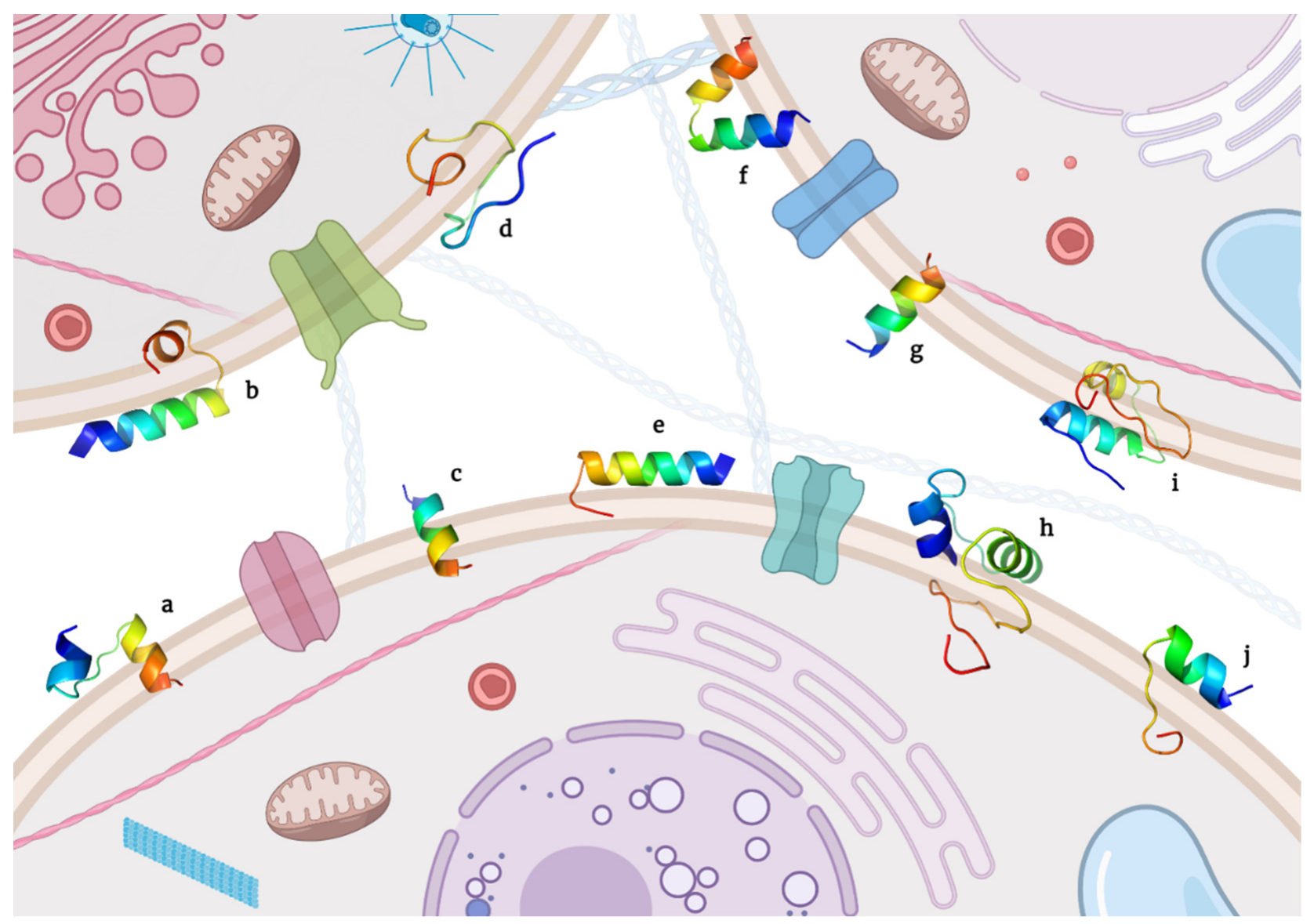

Figure 1. 3D models of candidate peptides as anticancer therapeutics inducing membrane damage. (a) Buforin Ilb, (b) ChMAP-28, (c) Decoralin, (d) Hepcidin isoforms TH1-5 and (e) TH2-3, (f) Magainin 2, (g) NaD1 defensin, (h) MP1, (i) Tachyplesin, and (j) Thionin. 


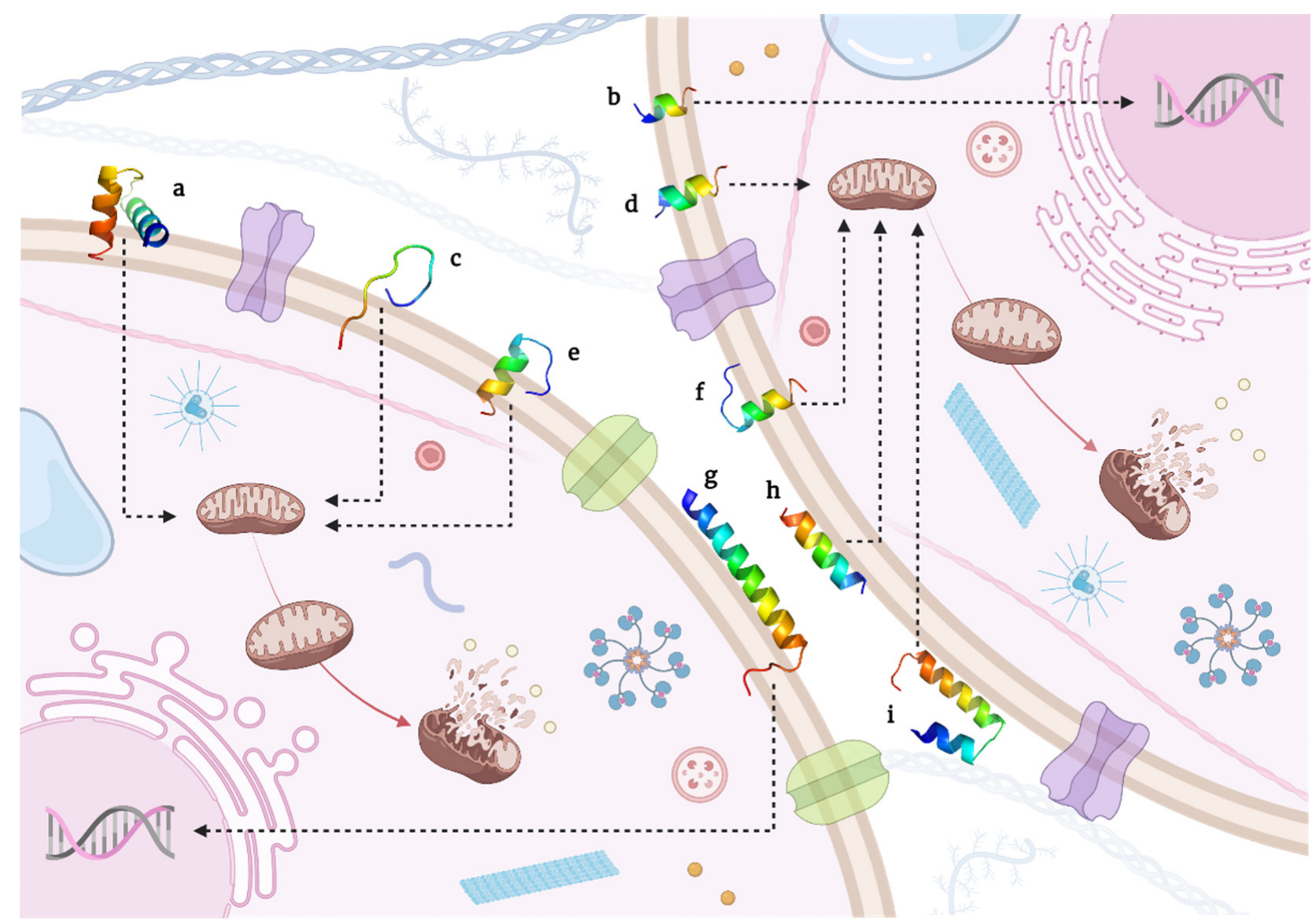

Figure 2. 3D models of candidate peptides as anticancer therapeutics inducing apoptotic cell death. (a) Cecropin XJ, (b) Cycas revoluta peptide, (c) GG, (d) LF11, (e) Leucrocins KT2 and (f) RT2, (g) LL-37 native, (h) FK-16 fragment, and (i) Pardaxin.

\subsection{Peptides Performing Membrane-Damaging Cell Death}

The effect on the cell membrane of peptides can be disruption, consequently resulting in cell lysis in a poorly controlled manner, resulting in the spilling of contents into the surrounding microenvironment (necrosis) [73]. Alternatively, their interaction with the membrane can form transient pores and then transport peptides inside cells, allowing them to interact with intracellular targets [95].

Table 1. Amino acid sequence of specific candidate peptides performing membrane damage.

\begin{tabular}{cccc}
\hline Key & Peptide & Amino Acid Sequence & Reference \\
\hline a & Buforin IIb & TRSSRAGLQFPVGRVHRLLRK & {$[96]$} \\
b & ChMAP-28 & GRFKRFRKKLKRLWHKVGPFVGPILHY & {$[97]$} \\
c & Decoralin & SLLSLIRKLIT & {$[98]$} \\
d & Hepcidin isoforms & GIKCRFCCGCCTPGICGVCCRF & {$[99,100]$} \\
$\&$ & TH1-5 and TH2-3 & QSHLSLCRWCCNCCRSNKGC & \\
e & Magainin 2 & GIGKFLHSAKKFGKAFVGEIMNS & {$[101]$} \\
$\mathrm{f}$ & NaD1 defensin & ARECKTESNTFPGICITKPPCRKACISEKFTDGHCSKILRRCLCTKPC & {$[102]$} \\
$\mathrm{g}$ & MP1 & ILGTILGLLKSL & {$[103]$} \\
$\mathrm{h}$ & Tachyplesin & KSWCFRVCYRGICYRRCR & {$[104]$} \\
$\mathrm{i}$ & Thionin & KSCCRNTWARNCYNVCRLPGTISREICAKKCDCKIISGTTCPSDYPK & {$[105]$} \\
\hline
\end{tabular}




\subsubsection{Buforin IIb}

Buforin IIb, a peptide derived from the histone 2A isolated from the Asiatic toad (Bufo bufo garagrizans), can translocate into the cytosol without membrane disruption then accumulate in the nuclei and, thereby, induce apoptosis [37]. Particularly, this peptide shifts itself through the plasmatic membrane through the formation of transient toroidal pores [106]. This peptide has induced cytotoxicity against breast, colon, and prostate cancer cell lines $[50,107]$. Nevertheless, the promising cytotoxicity of this peptide has been further improved with the production of a peptide with enhanced selectivity and with no toxicity for healthy cells, known as the BR2 peptide [108].

\subsubsection{ChMAP-28}

ChMAP-28 is an antimicrobial peptide from the leukocytes of Capra hircus [109]. This peptide is selective to cancerous cells and is non-hemolytic, making it a promising peptide for oncological treatment [110]. Particularly, the ChMAP-28 peptide shows the capacity to provoke necrosis in cancer cells through plasmatic membrane disruption [7]. Several studies on its properties have discovered that this peptide resulted in cytotoxicity for A431 epidermoid carcinoma, HL-60 acute promyelocytic leukemia, and SKBR-3 human breast adenocarcinoma cells [97].

\subsubsection{Decoralin-NH2}

Isolated from the venom of the Oreumenes decoratus wasp, decoralin-NH2 is another peptide that has demonstrated both antimicrobial and anticancer properties [111]. Specifically, decoralin-NH2 is capable of provoking necrosis through membrane micellization [112] in breast cancer (MCF-7) and sarcoma cells [7]. Reportedly, several analogs and modifications have been made to decoralin-NH2, which have shown similar anticancer activity but even less hemolysis $[113,114]$.

\subsubsection{Hepcidin}

Hepcidin is a peptide obtained from tilapia fish (Oreochromis mossambicus) [115]. Specifically, two of its isoforms, TH1-5 and TH2-3, have denoted cytotoxic effects [7]. TH1-5 changed the lipid membrane and induced necrosis in high concentrations and apoptosis in lower concentrations [116]. Moreover, TH1-5 and TH2-3 prevent cancer cell invasion through electrostatic interactions [7].

\subsubsection{Magainin 2}

Magainin 2 is an amphiphilic $\alpha$-helical membranolytic peptide obtained from the skin of the African frog (Xenopus laevis) [117]. This peptide also performs a synergistic antimicrobial activity [118]. The mechanism of action of magainin 2 is to rapidly induce ion channels causing leakage of ions such as $\mathrm{Cl}-, \mathrm{K}+$, and $\mathrm{Na}+[119]$. However, the cytotoxic effects of this peptide depend on the membrane potential [120]. Additionally, mitochondrial exposure to magainin 2 inhibits cellular respiration and leakage of glucose through peptide-induced channels [121].

\subsubsection{NaD1 Defensin}

Defensins are a class of plant antimicrobial peptides resembling an anticancer mechanism that remains poorly understood [122-126]. NaD1 defensin has generated interest due to its already elucidated effect on monocytic lymphoma cells U937 [15]. Such a mechanism consists of cell lysis through direct binding to the phospholipid phosphatidylinositol 4,5-bisphosphate $\left(\mathrm{PIP}_{2}\right)$ of plasmatic membranes [52,127].

\subsubsection{MP1 Peptide}

The antimicrobial peptide MP1, isolated from a Brazilian wasp (Polybia paulista) [128,129], has selectively inhibited various tumor cell lines [130]. This peptide causes perturbation of the cell membrane in a two-sequence process: (1) union of the MP1 peptide to the plasmatic 
membrane, and (2) membrane disruption through bound peptides-induced leakage [131], making it a possible adjuvant for novel chemotherapeutic therapies [132]. Based on this, the positively charged nature of this peptide is likely a relevant factor for the first step, in which the peptide binds to the plasmatic membrane in a structured form, e.g., a helix $[133,134]$. Likewise, membrane permeabilization is part of the mechanism of cancer cell death mediated by this peptide $[130,135,136]$.

\subsubsection{Tachyplesin}

Tachyplesins are host defense peptides from horseshoe crabs (Tachypleus tridentatus) displaying antimicrobial and anticancer properties [137]. These peptides have indicated a high affinity for plasmatic membrane and selectivity against cancer cells, causing cell death by membrane disruption or apoptosis [138]. Additionally, there are reports of A549 adenocarcinoma human alveolar basal epithelial cells exhibiting resistance against this peptide, putting in doubt its true potential as an anticancer therapeutic [139]. Nonetheless, certain studies have indicated that this peptide has high selectivity for melanoma cells and high efficacy to internalize itself into cancer cells [138].

\subsubsection{Thionins}

Interestingly, thionins were the first antimicrobial peptide obtained from plants [140,141]. Specifically, the thionin from mistletoe (Pyrularia pubera) reportedly has an anticancer effect, which has been attributed to a cellular response simultaneously triggering $\mathrm{Ca}^{2+}$ influx and depolarization of plasmatic membrane [142]. Notably, this peptide then activates endogenous phospholipase $A_{2}$, subsequently triggering membrane disruption and, eventually, cell death [143].

\subsection{Peptides Performing Apoptotic Cell Death}

The term "apoptosis" refers to the termination of cells in a programmed manner involving a series of molecular events [144]. Recently, the termed proapoptotic peptides have risen as novel cancer therapeutics [145].

Table 2. Amino acid sequence of specific candidate peptides performing apoptotic cell death.

\begin{tabular}{cccc}
\hline Key & Peptide & Amino Acid Sequence & Reference \\
\hline $\mathrm{a}$ & Cecropin XJ & WKIFKKIEKMGRNIRDGIVKAGPAIEVLGSAKAIGK & {$[146]$} \\
$\mathrm{b}$ & Cycas revoluta peptide & AWKLFDDGV & {$[147]$} \\
$\mathrm{c}$ & GG & GPPPQGGRPG & {$[148]$} \\
$\mathrm{d}$ & LF11 & FQWQRNMRKVR & {$[149]$} \\
$\mathrm{e}$ & Leucrocins KT2 & NGVQPKYKWWKWWKKWW & {$[150]$} \\
$\&$ & $\&$ & \& & \\
$\mathrm{f}$ & RT2 & NGVQPKYRWWRWWRRWW & \\
$\mathrm{g}$ & LL-37 native & FRKSKEKIGKEFKRIVQRIKDFLRNLVPRTES & \& \\
$\mathrm{\&}$ & FKd its & FKRIVQRIKDFLRNLV & {$[151,152]$} \\
$\mathrm{h}$ & FK-16 fragment & GFFALIPKIISSPLFKTLLAVGSALSSSGGQE & {$[153]$} \\
$\mathrm{i}$ & Pardaxin & & \\
\hline
\end{tabular}

\subsubsection{Cecropin XJ}

Cecropin XJ, obtained from the larvae of silkworms (Bombyx mori), has reported activity against cancers, such as leukemia, gastric, esophageal, and hepatocellular (cell line Huh-7) cancers [7]. Specifically, cecropin XJ can cause apoptosis and inhibit cancer cell proliferation through the mitochondrial apoptosis pathways [154]. Moreover, cecropin $\mathrm{XJ}$ targets phosphatidylserine and phosphatidylethanolamine, both found in cancer cells ${ }^{\prime}$ outer membrane, and targets phosphatidylglycerol and cardiolipin, which explains its interactions with the mitochondria during apoptosis [155]. 


\subsubsection{Cycas revoluta Peptide}

A small peptide with sequence AWKLFDDGV and a molecular mass of $1.050 \mathrm{KDa}$ was obtained from palm fern seeds (Cycas revoluta) $[147,156]$. This peptide induced the inhibition of cancer cell proliferation by disrupting nucleosome structures, thus inducing apoptosis through DNA binding [15,157]. Through this mechanism, this peptide has exhibited clear adverse effects on colon carcinoma (HCT15) and human epidermoid cancer (Hep2) cells [158].

\subsubsection{GG Peptide}

Human saliva has been one of the least studied sources of peptides. Nonetheless, research indicated that the coined GG peptide affects the capability of e-cadherin to stabilize adherent junctions, further causing apoptosis [159]. Moreover, the GG peptide induces the expression of the proapoptotic Bax protein, decreasing the Bcl-2/Bax ratio, thereby favoring apoptosis [160]. Thus, such results were considered promising for the potential use of saliva-derived peptides as therapeutic agents [161]. Nonetheless, further research must be conducted to better characterize salivary peptides as active against different cell lines and, thus, highlight the vast potential of these molecules [162].

\subsubsection{LF11 from Human Lactoferricin (hLFcin)}

hLFcin comprises the 1-45 amino acid residues of the N-terminus of human lactoferrin (hLF) [163]. Particularly, LF11 is an 11-amino-acid fragment of hLFcin that has been optimized for its activity against cancer membranes [164]. To induce apoptosis, this peptide enters the cell through the PS, exposing sites on the cancer cell surface to then reach negatively charged targets on the surface of mitochondria, such as phosphatidylserine [165] and cardiolipin [166]. The relatively slow action, combined with the observation of membrane blebbing, is an indication of membrane-mediated apoptosis [167].

\subsubsection{Leucrocins}

Isolated from crocodile leukocytes, leucrocin was engineered to improve its native features [168]. The most successful derivatives were KT2 and RT2 [150]. These peptides act as death ligands and upregulate death receptors such as TNF R1, Fas, and TRAIL R2 [7]. Because of the binding of these peptides, the FADD is activated, procaspase 8 is cleaved, the proapoptotic factor HTRA2 leaks from the mitochondria, and apoptosis ensues [169]. Furthermore, caspase-3, caspase-9, and Bax were significantly increased [170]. Likewise, studies have shown that KT2 and RT2 successfully inhibit colorectal, CaSki cervical, and HeLa cancer cells [171].

\subsubsection{LL-37 and Its FK-16 Fragment}

The human antimicrobial protein of $18 \mathrm{kDa}$ (hCAP18, mainly called LL-37) is the only cationic cathelicidin found in human secondary granules of neutrophils [172]. Specifically, it induces apoptosis through DNA fragmentation and mitochondrial depolarization, both independent of caspase activation [153], or through the intrinsic pathway [173]. Additionally, FK-16, a fragment of LL-37, induces apoptosis (caspase-independent) and autophagy through the common $\mathrm{p} 53-\mathrm{Bcl}-2 /$ Bax pathway [174].

\subsubsection{Pardaxin}

Pardaxin is a recognized peptide that was first isolated from the Red Sea Moses sole (Pardachirus marmoratus) [175]. The selective death induction of cancer cells has been attributed to its cationic net charge, which enables easy interaction with the anionic plasma membranes of cells [176]. The uptake of pardaxin into the cytosol allows it to bind to the mitochondria, which mostly contain phospholipids, phosphatidylethanolamine, phosphatidic acid, and cardiolipin [177]. This resulting cytochrome c leakage into the cytosol of HT-1080 cells after pardaxin treatment has been related to the pore-forming ability in mitochondrial membranes [178]. Likewise, the release of cytochrome $\mathrm{c}$ from the mitochondria into the 
cytosol results in the mitochondrion-mediated apoptotic pathway [179] and the activation of caspases 3/7 [180].

\section{In Vivo Studies of Natural Specific Peptides}

Until now, the majority of anticancer peptides has only been researched in vitro [181], thus one of the main limitations regarding the potential therapeutic applications of anticancer peptides is the scarcity of in vivo studies to support the results of in vitro experiments [182]. Precisely, this is the reason why this review addressed specific candidate peptides at such a research phase. The literature reports on hydrolysates from different sources containing peptides with known sequence [183].

A leading representative of natural peptides with recognized anticancer activity is lunasin [184]. This is a peptide composed of 43 amino acid residues and isolated from soybeans [185] and is recognized as containing the arginine-glycine-aspartic acid (RGD) cell adhesion motif located at its carboxyl end [186]. Interestingly, this motif preferentially binds to deacetylated histone $\mathrm{H} 4$ in vitro while, in vivo, inhibits histone $\mathrm{H} 3$ and $\mathrm{H} 4$ acetylation [187]. Moreover, lunasin increases apoptosis and inhibits caspase- 3 both in vitro and in vivo [188].

There are additional peptides with anticancer effects tested in vivo [189,190]. However, their structure is more complex than the candidates addressed in this review. In this regard, a remarkable polypeptide is Vglycin, a 37-residue purified from pea seeds [191]. Its capability to inhibit colon cancer growth in vivo was an important finding, as well as its mitochondrial swelling and nuclear chromatin condensation, thereby denoting it as a cancer therapeutic agent [192].

\section{Disadvantages of Peptides Targeting Cancer Cells}

Even though numerous anticancer peptides have been thoroughly described and their activity has been demonstrated, their use may be limited by their rapid kidney and liver clearance [193], protease degradation by hydrolysis [194], or instability in gastrointestinal tract [195] or body fluids, such as blood [196].

Due to these intrinsic limitations, some bioactive peptides usually undergo modifications, such as the use of D-aminoacid or unnatural aminoacids [50]. Further proposals for improvements of peptides in the body's environment include C- and N-terminal modifications, pegylation, post-translational modifications, such as glycosylation, and creating cyclized or stapled peptide structures to enhance biostability and blood circulation time $[93,197]$.

\section{Discussion}

As the cancer epidemic is still on the rise [198], a strategy to expand the options for cancer treatment is therapeutic peptides. While its definition remains in constant debate [17], the role of this research in this field is to focus on peptides already considered as drug candidates due to their remarkable results in nonclinical tests.

Herein, the level of knowledge of the specific pathways or mechanisms of action of such peptides was analyzed, given that both results are essential to move toward clinical trials. Moreover, the focus was specifically on peptides with a known amino acid sequence since there are many extracts and protein fractions with reported anticancer effects but without a clear molecular protagonist.

Particularly, this is due to the anticancer mechanism peptides, which vary from current traditional anticancer drugs [26]. In this regard, and very interestingly, among the peptides with damaging effects on the cell membrane, many of them denoted antimicrobial and anticancer effects which, accordingly, agreed with the non-specificity of the charge interaction mechanism. Specifically, peptides such as ChMAP-28 or decoralin- $\mathrm{NH}_{2}$ exhibited a broad spectrum of cancerous cell lines among their targets [7,97].

In contrast, studies involving different cell lines have exhibited a certain resistance to the effects of tachyplesins [139]. This drawback for clinical development is consonant 
with multiple in vitro and in vivo studies with promising results [199]; a disadvantage regarding those peptides is the induction of more targeted cell death. For instance, among the peptides with recognized mechanisms of apoptosis induction presented here, most of them have a broad capability of causing cell death by targeting mitochondria. This approach implies intervention in the behavior of cancerous cell mitochondria, thereby avoiding the spread of potentially mutated mitochondrial DNA and metastasis [200].

Moreover, certain candidates, such as cecropins or leucrocins, have been engineered to enhance their notable activities against cancer cells $[150,201]$. This is a current trend in which bioinformatic algorithms combine with machine learning, which is currently considered the future for the rational design of peptides [202]. In response, the synthesis of specific peptides based on previous in silico prediction and design would effectively reduce the time for the obtention of more reproducible and function-specific peptides.

Previously, specialists have already been encouraged to use this approach as part of their routine activities for peptide design [203]. So far, the strategy has resulted in remarkable data on its performance and applicability. For instance, the buforin IIb peptide, which, to our knowledge, is in its enhanced version of BR2 peptide, deserves to be considered for more advanced nonclinical testing based on its confirmed selectivity and null toxicity for healthy cells [108]. Additionally, the reports of certain peptides interacting with overexpressed plasmatic proteins, such as ATP-binding cassette subfamily B member 1 (ABCB1) [204], or displaying a more selective effect against specific cancer types, mainly attributed to the differences in membrane composition and electrochemical properties [46], point to a path that has not been fully considered for the improvement of new candidate peptides.

Generally, the intrinsic weaknesses of these peptides should be overcome with the aid of protein engineering, attempting to avoid poor chemical and physical stability, short circulating plasma half-life, and enzymatic degradation [19,21].

Furthermore, crescent technologies such as D-enantiomeric or peptide stapling can improve the similar-to-drugs features [205]. Likewise, efforts should be made to improve the capacity of many of these peptides to be innocuous to healthy cells and immune to cell resistance mechanisms, as it would represent notable progress for cancer treatment [23]. For instance, a targeted activation when approaching the vicinity of cancer cells, based either on relatively acidic $\mathrm{pH}$ or on cleavage by metalloproteinases [206]. Finally, studies should be extensive to consider novel peptides' roles as companions to recognized anticancer drugs, e.g., chemosensitizers [207].

Thus, the coming years will provide answers to whether this strategy results in largescale use of these candidate peptides.

\section{Conclusions}

Although peptide relevance as cancer therapeutics has increased over the years, the number of peptides with recognized sequence and specific mechanisms of action against cancer cells is still limited. Moreover, an essential part of these peptides relies on the non-specific mechanism of damaging the cell membrane. Thus, for now, appropriate recommendations should be to overcome the intrinsic weaknesses of instability in body fluids, kidney clearance, and protease degradation of candidate peptides, improve their sequences with unnatural amino acids or post-translational modifications, modify their chain terminal ends, create stapled structures to enhance their biostability and blood circulation time, as well as to use recognized mechanisms of apoptosis induction and enhance their capacities of non-toxicity to healthy cells and further avoid cell resistance.

Author Contributions: Conceptualization, P.A.T.-C. and S.G.-L.; investigation, P.A.T.-C. and C.D.V.-C.; writing-original draft preparation, P.A.T.-C. and C.D.V.-C.; writing-review and editing, P.A.T.-C.; supervision, S.G.-L.; project administration, S.G.-L.; funding acquisition, S.G.-L. All authors have read and agreed to the published version of the manuscript. 
Funding: This research was funded by CONACyT, grant number 627107 for doctoral studies and Monterrey Institute of Technology and Higher Education CAT 005.

Institutional Review Board Statement: Not applicable.

Informed Consent Statement: Not applicable.

Data Availability Statement: Not applicable.

Acknowledgments: P.A.T.-C. personally thanks CONACyT for his grant 627107 for doctoral studies, Tecnológico de Monterrey for his full-tuition scholarship, and Laura Margarita López-Castillo for her sponsorship of the editing software for final figures created with BioRender.com (access date: 18 November 2021). The role of the PyMOL Molecular Graphics System, Version 1.2r3pre (Schrödinger, LLC.), for the making of peptide 3D models from this work, is duly recognized.

Conflicts of Interest: The authors declare no conflict of interest.

\section{References}

1. Mutgan, A.C.; Besikcioglu, H.E.; Wang, S.; Friess, H.; Ceyhan, G.O.; Demir, I.E. Insulin/IGF-driven cancer cell-stroma crosstalk as a novel therapeutic target in pancreatic cancer. Mol. Cancer 2018, 17, 66. [CrossRef]

2. Soukup, T.; Lamb, B.W.; Arora, S.; Darzi, A.; Sevdalis, N.; Green, J.S.A. Successful strategies in implementing a multidisciplinary team working in the care of patients with cancer: An overview and synthesis of the available literature. J. Multidiscip. Healthc. 2018, 11, 49-61. [CrossRef] [PubMed]

3. Miller, K.D.; Nogueira, L.; Mariotto, A.B.; Rowland, J.H.; Yabroff, K.R.; Alfano, C.M.; Jemal, A.; Kramer, J.L.; Siegel, R.L. Cancer treatment and survivorship statistics, 2019. CA Cancer J. Clin. 2019, 69, 363-385. [CrossRef]

4. Hoda, M. Potential Alternatives to Conventional Cancer Therapeutic Approaches: The Way Forward. Curr. Pharm. Biotechnol. 2021, 22, 1141-1148. [CrossRef]

5. Dallavalle, S.; Dobričić, V.; Lazzarato, L.; Gazzano, E.; Machuqueiro, M.; Pajeva, I.; Tsakovska, I.; Zidar, N.; Fruttero, R. Improvement of conventional anti-cancer drugs as new tools against multidrug resistant tumors. Drug Resist. Updat. 2020, 50, 100682. [CrossRef] [PubMed]

6. Cui, W.; Aouidate, A.; Wang, S.; Yu, Q.; Li, Y.; Yuan, S. Discovering Anti-Cancer Drugs via Computational Methods. Front. Pharmacol. 2020, 11, 733. [CrossRef]

7. Eghtedari, M.; Jafari Porzani, S.; Nowruzi, B. Anticancer potential of natural peptides from terrestrial and marine environments: A review. Phytochem. Lett. 2021, 42, 87-103. [CrossRef]

8. Li, M.; Zhao, X.; Dai, J.; Yu, Z. Peptide therapeutics and assemblies for cancer immunotherapy. Sci. China Mater. 2019, 62, 1759-1781. [CrossRef]

9. Tyagi, A.; Tuknait, A.; Anand, P.; Gupta, S.; Sharma, M.; Mathur, D.; Joshi, A.; Singh, S.; Gautam, A.; Raghava, G.P.S. CancerPPD: A database of anticancer peptides and proteins. Nucleic Acids Res. 2015, 43, D837-D843. [CrossRef] [PubMed]

10. Singh, S.; Chaudhary, K.; Dhanda, S.K.; Bhalla, S.; Usmani, S.S.; Gautam, A.; Tuknait, A.; Agrawal, P.; Mathur, D.; Raghava, G.P.S. SATPdb: A database of structurally annotated therapeutic peptides. Nucleic Acids Res. 2015, 44, D1119-D1126. [CrossRef] [PubMed]

11. Usmani, S.S.; Bedi, G.; Samuel, J.S.; Singh, S.; Kalra, S.; Kumar, P.; Ahuja, A.A.; Sharma, M.; Gautam, A.; Raghava, G.P.S. THPdb: Database of FDA-approved peptide and protein therapeutics. PLoS ONE 2017, 12, e0181748. [CrossRef] [PubMed]

12. Chen, W.; Ding, H.; Feng, P.; Lin, H.; Chou, K.-C. iACP: A sequence-based tool for identifying anticancer peptides. Oncotarget 2016, 7, 16895. [CrossRef] [PubMed]

13. Boopathi, V.; Subramaniyam, S.; Malik, A.; Lee, G.; Manavalan, B.; Yang, D.C. MACppred: A support vector machine-based meta-predictor for identification of anticancer peptides. Int. J. Mol. Sci. 2019, 20, 1964. [CrossRef] [PubMed]

14. Wang, G.; Li, X.; Wang, Z. APD2: The updated antimicrobial peptide database and its application in peptide design. Nucleic Acids Res. 2009, 37, 933-937. [CrossRef]

15. Guzmán-Rodríguez, J.J.; Ochoa-Zarzosa, A.; López-Gómez, R.; López-Meza, J.E. Plant antimicrobial peptides as potential anticancer agents. Biomed Res. Int. 2015, 2015, 735087. [CrossRef] [PubMed]

16. Wu, L. Regulatory Considerations for Peptide Therapeutics. In Peptide Therapeutics: Strategy and Tactics for Chemistry, Manufacturing, and Controls; Royal Society of Chemistry: Cambridge, UK, 2019; pp. 1-30, ISBN 978-1-78801-644-5.

17. D'Aloisio, V.; Dognini, P.; Hutcheon, G.A.; Coxon, C.R. PepTherDia: Database and structural composition analysis of approved peptide therapeutics and diagnostics. Drug Discov. Today 2021, 26, 1409-1419. [CrossRef] [PubMed]

18. Li, Q.; Zhang, C.; Chen, H.; Xue, J.; Guo, X.; Liang, M.; Chen, M. BioPepDB: An integrated data platform for food-derived bioactive peptides. Int. J. Food Sci. Nutr. 2018, 69, 963-968. [CrossRef] [PubMed]

19. Farsinejad, S.; Gheisary, Z.; Ebrahimi Samani, S.; Alizadeh, A.M. Mitochondrial targeted peptides for cancer therapy. Tumor Biol. 2015, 36, 5715-5725. [CrossRef]

20. Li, Y.; Yu, J. Research Progress in Structure-Activity Relationship of Bioactive Peptides. J. Med. Food 2015, 18, 147-156. [CrossRef] 
21. Fosgerau, K.; Hoffmann, T. Peptide therapeutics: Current status and future directions. Drug Discov. Today 2015, 20, 122-128. [CrossRef]

22. Karami, Z.; Akbari-Adergani, B. Bioactive food derived peptides: A review on correlation between structure of bioactive peptides and their functional properties. J. Food Sci. Technol. 2019, 56, 535-547. [CrossRef] [PubMed]

23. Habault, J.; Poyet, J.-L. Recent Advances in Cell Penetrating Peptide-Based Anticancer Therapies. Molecules $2019,24,927$. [CrossRef] [PubMed]

24. Kang, H.; Choi, M.-C.; Seo, C.; Park, Y. Therapeutic Properties and Biological Benefits of Marine-Derived Anticancer Peptides. Int. J. Mol. Sci. 2018, 19, 919. [CrossRef] [PubMed]

25. Dang, T.; Süssmuth, R.D. Bioactive Peptide Natural Products as Lead Structures for Medicinal Use. Acc. Chem. Res. 2017, 50, 1566-1576. [CrossRef] [PubMed]

26. Mishra, A.; Gauri, S.S.; Mukhopadhyay, S.K.; Chatterjee, S.; Das, S.S.; Mandal, S.M.; Dey, S. Identification and structural characterization of a new pro-apoptotic cyclic octapeptide cyclosaplin from somatic seedlings of Santalum album L. Peptides 2014, 54, 148-158. [CrossRef] [PubMed]

27. Sarojini, V.; Cameron, A.J.; Varnava, K.G.; Denny, W.A.; Sanjayan, G. Cyclic Tetrapeptides from Nature and Design: A Review of Synthetic Methodologies, Structure, and Function. Chem. Rev. 2019. [CrossRef] [PubMed]

28. Li, L.; Vorobyov, I.; Allen, T.W. The different interactions of lysine and arginine side chains with lipid membranes. J. Phys. Chem. B 2013, 117, 11906-11920. [CrossRef]

29. Armstrong, C.T.; Mason, P.E.; Anderson, J.L.R.; Dempsey, C.E. Arginine side chain interactions and the role of arginine as a gating charge carrier in voltage sensitive ion channels. Sci. Rep. 2016, 6, 21759. [CrossRef]

30. Kang, M.H.; Park, M.J.; Yoo, H.J.; Hyuk, K.Y.; Lee, S.G.; Kim, S.R.; Yeom, D.W.; Kang, M.J.; Choi, Y.W. RIPL peptide (IPLVVPLRRRRRRRRC)-conjugated liposomes for enhanced intracellular drug delivery to hepsin-expressing cancer cells. Eur. J. Pharm. Biopharm. 2014, 87, 489-499. [CrossRef]

31. Sultana, A.; Luo, H.; Ramakrishna, S. Antimicrobial peptides and their applications in biomedical sector. Antibiotics 2021, 10, 1094. [CrossRef]

32. Schaduangrat, N.; Nantasenamat, C.; Prachayasittikul, V.; Shoombuatong, W. ACPred: A Computational Tool for the Prediction and Analysis of Anticancer Peptides. Molecules 2019, 24, 1973. [CrossRef]

33. Huang, Y.; Feng, Q.; Yan, Q.; Hao, X.; Chen, Y. Alpha-Helical Cationic Anticancer Peptides: A Promising Candidate for Novel Anticancer Drugs. Mini-Rev. Med. Chem. 2015, 15, 73-81. [CrossRef] [PubMed]

34. Gabernet, G.; Gautschi, D.; Müller, A.T.; Neuhaus, C.S.; Armbrecht, L.; Dittrich, P.S.; Hiss, J.A.; Schneider, G. In silico design and optimization of selective membranolytic anticancer peptides. Sci. Rep. 2019, 9, 11282. [CrossRef] [PubMed]

35. Ditzinger, F.; Price, D.J.; Ilie, A.R.; Köhl, N.J.; Jankovic, S.; Tsakiridou, G.; Aleandri, S.; Kalantzi, L.; Holm, R.; Nair, A.; et al. Lipophilicity and hydrophobicity considerations in bio-enabling oral formulations approaches-A pearrl review. J. Pharm. Pharmacol. 2019, 71, 464-482. [CrossRef] [PubMed]

36. Oelkrug, C.; Hartke, M.; Schubert, A. Mode of action of anticancer peptides (ACPs) from amphibian origin. Anticancer Res. 2015, 35, 635-643.

37. Gabernet, G.; Müller, A.T.; Hiss, J.A.; Schneider, G. Membranolytic anticancer peptides. MedChemComm 2016, 7, $2232-2245$. [CrossRef]

38. Sun, X.; Acquah, C.; Aluko, R.E.; Udenigwe, C.C. Considering food matrix and gastrointestinal effects in enhancing bioactive peptide absorption and bioavailability. J. Funct. Foods 2020, 64, 103680. [CrossRef]

39. Smolarczyk, T.; Roterman-Konieczna, I.; Stapor, K. Protein Secondary Structure Prediction: A Review of Progress and Directions. Curr. Bioinform. 2019, 15, 90-107. [CrossRef]

40. Ma, Y.; Wu, Y.; Li, L. Relationship between primary structure or spatial conformation and functional activity of antioxidant peptides from Pinctada fucata. Food Chem. 2018, 264, 108-117. [CrossRef] [PubMed]

41. Sah, B.N.P.; Vasiljevic, T.; McKechnie, S.; Donkor, O.N. Identification of Anticancer Peptides from Bovine Milk Proteins and Their Potential Roles in Management of Cancer: A Critical Review. Compr. Rev. Food Sci. Food Saf. 2015, 14, 123-138. [CrossRef]

42. Janairo, J.I.B.; Janairo, G.C. Predicting Peptide Oligomeric State through Chemical Artificial Intelligence. Int. J. Pept. Res. Ther. 2021, 27, 763-767. [CrossRef]

43. Vargas Casanova, Y.; Rodríguez Guerra, J.A.; Umaña Pérez, Y.A.; Leal Castro, A.L.; Almanzar Reina, G.; García Castañeda, J.E.; Rivera Monroy, Z.J. Antibacterial Synthetic Peptides Derived from Bovine Lactoferricin Exhibit Cytotoxic Effect against MDA-MB-468 and MDA-MB-231 Breast Cancer Cell Lines. Molecules 2017, 22, 1641. [CrossRef] [PubMed]

44. Nyström, L.; Malmsten, M. Membrane interactions and cell selectivity of amphiphilic anticancer peptides. Curr. Opin. Colloid Interface Sci. 2018, 38, 1-7. [CrossRef]

45. Tan, J.; Tay, J.; Hedrick, J.; Yang, Y.Y. Synthetic macromolecules as therapeutics that overcome resistance in cancer and microbial infection. Biomaterials 2020, 252, 120078. [CrossRef] [PubMed]

46. Vitale, I.; Yamazaki, T.; Wennerberg, E.; Sveinbjørnsson, B.; Rekdal, Ø.; Demaria, S.; Galluzzi, L. Targeting Cancer Heterogeneity with Immune Responses Driven by Oncolytic Peptides. Trends Cancer 2021, 7, 557-572. [CrossRef] [PubMed]

47. Kaushik, A.C.; Mehmood, A.; Peng, S.; Zhang, Y.J.; Dai, X.; Wei, D.Q. A-CaMP: A tool for anti-cancer and antimicrobial peptide generation. J. Biomol. Struct. Dyn. 2020, 39, 285-293. [CrossRef] [PubMed] 
48. Sharma, B.; Kanwar, S.S. Phosphatidylserine: A cancer cell targeting biomarker. Semin. Cancer Biol. 2018, 52, 17-25. [CrossRef] [PubMed]

49. Piotrowska, U.; Sobczak, M.; Oledzka, E. Current state of a dual behaviour of antimicrobial peptides-Therapeutic agents and promising delivery vectors. Chem. Biol. Drug Des. 2017, 90, 1079-1093. [CrossRef]

50. Tornesello, A.L.; Borrelli, A.; Buonaguro, L.; Buonaguro, F.M.; Tornesello, M.L. Antimicrobial Peptides as Anticancer Agents: Functional Properties and Biological Activities. Molecules 2020, 25, 2850. [CrossRef]

51. Leuschner, C.; Hansel, W. Membrane Disrupting Lytic Peptides for Cancer Treatments. Curr. Pharm. Des. 2005, 10, 2299-2310. [CrossRef]

52. Baxter, A.A.; Lay, F.T.; Poon, I.K.H.; Kvansakul, M.; Hulett, M.D. Tumor cell membrane-targeting cationic antimicrobial peptides: Novel insights into mechanisms of action and therapeutic prospects. Cell. Mol. Life Sci. 2017, 74, 3809-3825. [CrossRef]

53. Felício, M.R.; Silva, O.N.; Gonçalves, S.; Santos, N.C.; Franco, O.L. Peptides with Dual Antimicrobial and Anticancer Activities. Front. Chem. 2017, 5, 5. [CrossRef] [PubMed]

54. Kunda, N.K. Antimicrobial peptides as novel therapeutics for non-small cell lung cancer. Drug Discov. Today 2020, 25, 238-247. [CrossRef] [PubMed]

55. Ciumac, D.; Gong, H.; Hu, X.; Lu, J.R. Membrane targeting cationic antimicrobial peptides. J. Colloid Interface Sci. 2019, 537, 163-185. [CrossRef] [PubMed]

56. Izzi, V.; Heljasvaara, R.; Pihlajaniemi, T. Understanding the extracellular matrix in acute myeloid leukemia. Haematologica 2017, 102, 1807-1809. [CrossRef]

57. Chan, S.C.; Hui, L.; Chen, H.M. Enhancement of the cytolytic effect of anti-bacterial cecropin by the microvilli of cancer cells. Anticancer Res. 1998, 18, 4467-4474.

58. Garizo, A.R.; Coelho, L.F.; Pinto, S.; Dias, T.P.; Fernandes, F.; Bernardes, N.; Fialho, A.M. The azurin-derived peptide ct-p19lc exhibits membrane-active properties and induces cancer cell death. Biomedicines 2021, 9, 1194. [CrossRef]

59. Liao, W.; Lai, T.; Chen, L.; Fu, J.; Sreenivasan, S.T.; Yu, Z.; Ren, J. Synthesis and Characterization of a Walnut Peptides-Zinc Complex and Its Antiproliferative Activity against Human Breast Carcinoma Cells through the Induction of Apoptosis. J. Agric. Food Chem. 2016, 64, 1509-1519. [CrossRef]

60. Riedl, S.; Leber, R.; Rinner, B.; Schaider, H.; Lohner, K.; Zweytick, D. Human lactoferricin derived di-peptides deploying loop structures induce apoptosis specifically in cancer cells through targeting membranous phosphatidylserine. Biochim. Biophys. Acta-Biomembr. 2015, 1848, 2918-2931. [CrossRef]

61. Gaspar, D.; Salomé Veiga, A.; Castanho, M.A.R.B. From antimicrobial to anticancer peptides. A review. Front. Microbiol. 2013, 4, 294. [CrossRef]

62. Mesa-Galloso, H.; Pedrera, L.; Ros, U. Pore-forming proteins: From defense factors to endogenous executors of cell death. Chem. Phys. Lipids 2021, 234, 105026. [CrossRef] [PubMed]

63. Lipkin, R.; Lazaridis, T. Computational studies of peptide-induced membrane pore formation. Philos. Trans. R. Soc. B Biol. Sci. 2017, 372, 20160219. [CrossRef]

64. Sepehri, A.; PeBenito, L.; Pino-Angeles, A.; Lazaridis, T. What Makes a Good Pore Former: A Study of Synthetic Melittin Derivatives. Biophys. J. 2020, 118, 1901-1913. [CrossRef]

65. Wimley, W.C.; Hristova, K. The Mechanism of Membrane Permeabilization by Peptides: Still an Enigma. Aust. J. Chem. 2020, 73, 96-103. [CrossRef]

66. Pitsalidis, C.; Pappa, A.M.; Porel, M.; Artim, C.M.; Faria, G.C.; Duong, D.D.; Alabi, C.A.; Daniel, S.; Salleo, A.; Owens, R.M. Biomimetic Electronic Devices for Measuring Bacterial Membrane Disruption. Adv. Mater. 2018, 30, 1803130. [CrossRef] [PubMed]

67. Togo, T. Autocrine purinergic signaling stimulated by cell membrane disruption is involved in both cell membrane repair and adaptive response in MDCK cells. Biochem. Biophys. Res. Commun. 2019, 511, 161-164. [CrossRef] [PubMed]

68. Liu, X.; Li, Y.; Li, Z.; Lan, X.; Leung, P.H.-M.; Li, J.; Yang, M.; Ko, F.; Qin, L. Mechanism of Anticancer Effects of Antimicrobial Peptides. J. Fiber Bioeng. Inform. 2015, 8, 25-36. [CrossRef]

69. Dennison, S.R.; Harris, F.; Phoenix, D.A. Investigations into the potential anticancer activity of Maximin H5. Biochimie 2017, 137, 29-34. [CrossRef]

70. Sekiya, Y.; Sakashita, S.; Shimizu, K.; Usui, K.; Kawano, R. Channel current analysis estimates the pore-formation and the penetration of transmembrane peptides. Analyst 2018, 143, 3540-3543. [CrossRef] [PubMed]

71. Tang, D.; Kang, R.; Berghe, T.V.; Vandenabeele, P.; Kroemer, G. The molecular machinery of regulated cell death. Cell Res. 2019, 29, 347-364. [CrossRef]

72. Braicu, C.; Zanoaga, O.; Zimta, A.A.; Tigu, A.B.; Kilpatrick, K.L.; Bishayee, A.; Nabavi, S.M.; Berindan-Neagoe, I. Natural compounds modulate the crosstalk between apoptosis- and autophagy-regulated signaling pathways: Controlling the uncontrolled expansion of tumor cells. Semin. Cancer Biol. 2020. [CrossRef] [PubMed]

73. D'Arcy, M.S. Cell death: A review of the major forms of apoptosis, necrosis and autophagy. Cell Biol. Int. 2019, 43, 582-592. [CrossRef] [PubMed]

74. Chen, Q.; Kang, J.; Fu, C. The independence of and associations among apoptosis, autophagy, and necrosis. Signal Transduct. Target. Ther. 2018, 3, 1. [CrossRef] [PubMed] 
75. Alharbi, K.S.; Fuloria, N.K.; Fuloria, S.; Rahman, S.B.; Al-Malki, W.H.; Javed Shaikh, M.A.; Thangavelu, L.; Singh, S.K.; Rama Raju Allam, V.S.; Jha, N.K.; et al. Nuclear factor-kappa B and its role in inflammatory lung disease. Chem. Biol. Interact. 2021, 345, 109568. [CrossRef]

76. Tonnus, W.; Meyer, C.; Paliege, A.; Belavgeni, A.; von Mässenhausen, A.; Bornstein, S.R.; Hugo, C.; Becker, J.U.; Linkermann, A. The pathological features of regulated necrosis. J. Pathol. 2019, 247, 697-707. [CrossRef] [PubMed]

77. Grootjans, S.; Vanden Berghe, T.; Vandenabeele, P. Initiation and execution mechanisms of necroptosis: An overview. Cell Death Differ. 2017, 24, 1184-1195. [CrossRef] [PubMed]

78. Pfeffer, C.M.; Singh, A.T.K. Apoptosis: A target for anticancer therapy. Int. J. Mol. Sci. 2018, 19, 448. [CrossRef] [PubMed]

79. Kesavardhana, S.; Malireddi, R.K.S.; Kanneganti, T.D. Caspases in Cell Death, Inflammation, and Pyroptosis. Annu. Rev. Immunol. 2020, 38, 567-595. [CrossRef]

80. Mohammadinejad, R.; Moosavi, M.A.; Tavakol, S.; Vardar, D.Ö.; Hosseini, A.; Rahmati, M.; Dini, L.; Hussain, S.; Mandegary, A.; Klionsky, D.J. Necrotic, apoptotic and autophagic cell fates triggered by nanoparticles. Autophagy 2019, 15, 4-33. [CrossRef] [PubMed]

81. Li, Z.; Yuan, W.; Lin, Z. Functional roles in cell signaling of adaptor protein TRADD from a structural perspective. Comput. Struct. Biotechnol. J. 2020, 18, 2867-2876. [CrossRef] [PubMed]

82. Füllsack, S.; Rosenthal, A.; Wajant, H.; Siegmund, D. Redundant and receptor-specific activities of TRADD, RIPK1 and FADD in death receptor signaling. Cell Death Dis. 2019, 10, 122. [CrossRef] [PubMed]

83. Mouasni, S.; Tourneur, L. FADD at the Crossroads between Cancer and Inflammation. Trends Immunol. 2018, 39, 1036-1053. [CrossRef] [PubMed]

84. Ivanisenko, N.V.; Lavrik, I.N. Mechanisms of Procaspase-8 Activation in the Extrinsic Programmed Cell Death Pathway. Mol. Biol. 2019, 53, 732-738. [CrossRef]

85. Holbrook, J.; Lara-Reyna, S.; Jarosz-Griffiths, H.; McDermott, M. Tumour necrosis factor signalling in health and disease [version 1; referees: 2 approved]. F1000Research 2019, 8. [CrossRef] [PubMed]

86. Wallach, D. The tumor necrosis factor family: Family conventions and private idiosyncrasies. Cold Spring Harb. Perspect. Biol. 2018, 10, a028431. [CrossRef] [PubMed]

87. Morris, G.; Walker, A.J.; Berk, M.; Maes, M.; Puri, B.K. Cell Death Pathways: A Novel Therapeutic Approach for Neuroscientists. Mol. Neurobiol. 2018, 55, 5767-5786. [CrossRef]

88. Liu, G.; Yuan, Y.; Long, M.; Luo, T.; Bian, J.; Liu, X.; Gu, J.; Zou, H.; Song, R.; Wang, Y.; et al. Beclin-1-mediated Autophagy Protects Against Cadmium-activated Apoptosis via the Fas/FasL Pathway in Primary Rat Proximal Tubular Cell Culture. Sci. Rep. 2017, 7, 977. [CrossRef] [PubMed]

89. Warren, C.F.A.; Wong-Brown, M.W.; Bowden, N.A. BCL-2 family isoforms in apoptosis and cancer. Cell Death Dis. 2019, 10, 177. [CrossRef] [PubMed]

90. Peña-Blanco, A.; García-Sáez, A.J. Bax, Bak and beyond-Mitochondrial performance in apoptosis. FEBS J. 2018, $285,416-431$. [CrossRef]

91. Jan, R.; Chaudhry, G.-S. Understanding Apoptosis and Apoptotic Pathways Targeted Cancer Therapeutics. Adv. Pharm. Bull. 2019, 9, 205-218. [CrossRef] [PubMed]

92. Shakeri, R.; Kheirollahi, A.; Davoodi, J. Apaf-1: Regulation and function in cell death. Biochimie 2017, 135, 111-125. [CrossRef]

93. Wang, S.H.; Yu, J. Structure-based design for binding peptides in anti-cancer therapy. Biomaterials 2018, 156, 1-15. [CrossRef] [PubMed]

94. Gerlach, S.L.; Rathinakumar, R.; Chakravarty, G.; Göransson, U.; Wimley, W.C.; Darwin, S.P.; Mondal, D. Anticancer and chemosensitizing abilities of cycloviolacin $\mathrm{O} 2$ from Viola odorata and psyle cyclotides from Psychotria leptothyrsa. Biopolymers 2010, 94, 617-625. [CrossRef]

95. Li, Y.; Xiang, Q.; Zhang, Q.; Huang, Y.; Su, Z. Overview on the recent study of antimicrobial peptides: Origins, functions, relative mechanisms and application. Peptides 2012, 37, 207-215. [CrossRef] [PubMed]

96. Lan, Y.; Ye, Y.; Kozlowska, J.; Lam, J.K.W.; Drake, A.F.; Mason, A.J. Structural contributions to the intracellular targeting strategies of antimicrobial peptides. Biochim. Biophys. Acta-Biomembr. 2010, 1798, 1934-1943. [CrossRef]

97. Emelianova, A.A.; Kuzmin, D.V.; Panteleev, P.V.; Sorokin, M.; Buzdin, A.A.; Ovchinnikova, T.V. Anticancer Activity of the Goat Antimicrobial Peptide ChMAP-28. Front. Pharmacol. 2018, 9, 1501. [CrossRef] [PubMed]

98. Konno, K.; Rangel, M.; Oliveira, J.S.; dos Santos Cabrera, M.P.; Fontana, R.; Hirata, I.Y.; Hide, I.; Nakata, Y.; Mori, K.; Kawano, M.; et al. Decoralin, a novel linear cationic $\alpha$-helical peptide from the venom of the solitary eumenine wasp Oreumenes decoratus. Peptides 2007, 28, 2320-2327. [CrossRef] [PubMed]

99. Lo, Y.L.; Lee, H.P.; Tu, W.C. The Use of a Liposomal Formulation Incorporating an Antimicrobial Peptide from Tilapia as a New Adjuvant to Epirubicin in Human Squamous Cell Carcinoma and Pluripotent Testicular Embryonic Carcinoma Cells. Int. J. Mol. Sci. 2015, 16, 22711-22734. [CrossRef]

100. Chen, J.Y.; Lin, W.J.; Lin, T.L. A fish antimicrobial peptide, tilapia hepcidin TH2-3, shows potent antitumor activity against human fibrosarcoma cells. Peptides 2009, 30, 1636-1642. [CrossRef] [PubMed]

101. Aisenbrey, C.; Amaro, M.; Pospíšil, P.; Hof, M.; Bechinger, B. Highly synergistic antimicrobial activity of magainin 2 and PGLa peptides is rooted in the formation of supramolecular complexes with lipids. Sci. Rep. 2020, 10, 11652. [CrossRef] 
102. Järvå, M.; Lay, F.T.; Phan, T.K.; Humble, C.; Poon, I.K.H.; Bleackley, M.R.; Anderson, M.A.; Hulett, M.D.; Kvansakul, M. X-ray structure of a carpet-like antimicrobial defensin-phospholipid membrane disruption complex. Nat. Commun. 2018, $9,1962$. [CrossRef] [PubMed]

103. Souza, B.M.; Mendes, M.A.; Santos, L.D.; Marques, M.R.; César, L.M.M.; Almeida, R.N.A.; Pagnocca, F.C.; Konno, K.; Palma, M.S. Structural and functional characterization of two novel peptide toxins isolated from the venom of the social wasp Polybia paulista. Peptides 2005, 26, 2157-2164. [CrossRef] [PubMed]

104. Laederach, A.; Andreotti, A.H.; Bruce Fulton, D. Solution and Micelle-Bound Structures of Tachyplesin I and Its Active Aromatic Linear Derivatives. Biochemistry 2002, 41, 12359-12368. [CrossRef] [PubMed]

105. Vila-Perelló, M.; Sánchez-Vallet, A.; García-Olmedo, F.; Molina, A.; Andreu, D. Synthetic and structural studies on Pyrularia pubera thionin: A single-residue mutation enhances activity against Gram-negative bacteria. FEBS Lett. 2003, 536, 215-219. [CrossRef]

106. Cardoso, M.H.; Meneguetti, B.T.; Costa, B.O.; Buccini, D.F.; Oshiro, K.G.N.; Preza, S.L.E.; Carvalho, C.M.E.; Migliolo, L.; Franco, O.L. Non-lytic antibacterial peptides that translocate through bacterial membranes to act on intracellular targets. Int. J. Mol. Sci. 2019, 20, 4877. [CrossRef] [PubMed]

107. Li, D.; Xu, Y. Buforin Ilb induced cell cycle arrest in liver cancer. Anim. Cells Syst. 2019, 23, 176-183. [CrossRef]

108. Liscano, Y.; Oñate-Garzón, J.; Delgado, J.P. Peptides with dual antimicrobial-anticancer activity: Strategies to overcome peptide limitations and rational design of anticancer peptides. Molecules 2020, 25, 4245. [CrossRef] [PubMed]

109. Hao, Y.; Yang, N.; Teng, D.; Wang, X.; Mao, R.; Wang, J. A review of the design and modification of lactoferricins and their derivatives. BioMetals 2018, 31, 331-341. [CrossRef]

110. Oliva Arguelles, B.; Riera-Romo, M.; Guerra Vallespi, M. Antitumour peptide based on a protein derived from the horseshoe crab: CIGB-552 a promising candidate for cancer therapy. Br. J. Pharmacol. 2020, 177, 3625-3634. [CrossRef] [PubMed]

111. Abd El-Wahed, A.; Yosri, N.; Sakr, H.H.; Du, M.; Algethami, A.F.M.; Zhao, C.; Abdelazeem, A.H.; Tahir, H.E.; Masry, S.H.D.; AbdelDaim, M.M.; et al. Wasp Venom Biochemical Components and Their Potential in Biological Applications and Nanotechnological Interventions. Toxins 2021, 13, 206. [CrossRef] [PubMed]

112. Pillong, M.; Hiss, J.A.; Schneider, P.; Lin, Y.-C.; Posselt, G.; Pfeiffer, B.; Blatter, M.; Müller, A.T.; Bachler, S.; Neuhaus, C.S.; et al. Rational Design of Membrane-Pore-Forming Peptides. Small 2017, 13, 1701316. [CrossRef]

113. Torres, M.D.T.; Andrade, G.P.; Sato, R.H.; Pedron, C.N.; Manieri, T.M.; Cerchiaro, G.; Ribeiro, A.O.; De la Fuente-Nunez, C.; Oliveira, V.X. Natural and redesigned wasp venom peptides with selective antitumoral activity. Beilstein J. Org. Chem. 2018, 14, 1693-1703. [CrossRef] [PubMed]

114. Torres, M.D.T.; Pedron, C.N.; da Silva Lima, J.A.; da Silva, P.I.; da Silva, F.D.; Oliveira, V.X. Antimicrobial activity of leucinesubstituted decoralin analogs with lower hemolytic activity. J. Pept. Sci. 2017, 23, 818-823. [CrossRef] [PubMed]

115. Ting, C.H.; Pan, C.Y.; Chen, Y.C.; Lin, Y.C.; Chen, T.Y.; Rajanbabu, V.; Chen, J.Y. Impact of Tilapia hepcidin 2-3 dietary supplementation on the gut microbiota profile and immunomodulation in the grouper (Epinephelus lanceolatus). Sci. Rep. 2019, 9, 19047. [CrossRef] [PubMed]

116. Chang, W.T.; Pan, C.Y.; Rajanbabu, V.; Cheng, C.W.; Chen, J.Y. Tilapia (Oreochromis mossambicus) antimicrobial peptide, hepcidin 1-5, shows antitumor activity in cancer cells. Peptides 2011, 32, 342-352. [CrossRef]

117. Kim, M.K.; Kang, N.; Ko, S.J.; Park, J.; Park, E.; Shin, D.W.; Kim, S.H.; Lee, S.A.; Lee, J.I.; Lee, S.H.; et al. Antibacterial and antibiofilm activity and mode of action of magainin 2 against drug-resistant acinetobacter baumannii. Int. J. Mol. Sci. 2018, 19, 3041. [CrossRef] [PubMed]

118. Zerweck, J.; Strandberg, E.; Kukharenko, O.; Reichert, J.; Bürck, J.; Wadhwani, P.; Ulrich, A.S. Molecular mechanism of synergy between the antimicrobial peptides PGLa and magainin 2. Sci. Rep. 2017, 7, 13153. [CrossRef]

119. Rashid, M.M.O.; Moghal, M.M.R.; Billah, M.M.; Hasan, M.; Yamazaki, M. Effect of membrane potential on pore formation by the antimicrobial peptide magainin 2 in lipid bilayers. Biochim. Biophys. Acta-Biomembr. 2020, 1862, 183381. [CrossRef]

120. Liu, S.; Yang, H.; Wan, L.; Cai, H.W.; Li, S.F.; Li, Y.P.; Cheng, J.Q.; Lu, X.F. Enhancement of cytotoxicity of antimicrobial peptide magainin II in tumor cells by bombesin-targeted delivery. Acta Pharmacol. Sin. 2011, 32, 79-88. [CrossRef] [PubMed]

121. Deslouches, B.; Peter Di, Y. Antimicrobial peptides with selective antitumor mechanisms: Prospect for anticancer applications. Oncotarget 2017, 8, 46635-46651. [CrossRef]

122. De Oliveira Carvalho, A.; Moreira Gomes, V. Plant Defensins and Defensin-Like Peptides-Biological Activities and Biotechnological Applications. Curr. Pharm. Des. 2012, 17, 4270-4293. [CrossRef]

123. Silva, P.M.; Gonçalves, S.; Santos, N.C. Defensins: Antifungal lessons from eukaryotes. Front. Microbiol. 2014, 5, 97. [CrossRef] [PubMed]

124. Vriens, K.; Cammue, B.; Thevissen, K. Antifungal Plant Defensins: Mechanisms of Action and Production. Molecules 2014, 19, 12280-12303. [CrossRef]

125. Phan, T.K.; Lay, F.T.; Poon, I.K.H.; Hinds, M.G.; Kvansakul, M.; Hulett, M.D. Human $\beta$-defensin 3 contains an oncolytic motif that binds PI(4,5)P2 to mediate tumour cell permeabilisation. Oncotarget 2016, 7, 2054-2069. [CrossRef]

126. Shafee, T.M.A.; Lay, F.T.; Phan, T.K.; Anderson, M.A.; Hulett, M.D. Convergent evolution of defensin sequence, structure and function. Cell. Mol. Life Sci. 2017, 74, 663-682. [CrossRef]

127. Baxter, A.A.; Poon, I.K.H.; Hulett, M.D. The plant defensin NaD1 induces tumor cell death via a non-apoptotic, membranolytic process. Cell Death Discov. 2017, 3, 16102. [CrossRef] 
128. Dos Santos Cabrera, M.P.; Arcisio-Miranda, M.; Gorjão, R.; Leite, N.B.; De Souza, B.M.; Curi, R.; Procopio, J.; Ruggiero Neto, J.; Palma, M.S. Influence of the bilayer composition on the binding and membrane disrupting effect of polybia-MP1, an antimicrobial mastoparan peptide with leukemic T-lymphocyte cell selectivity. Biochemistry 2012, 51, 4898-4908. [CrossRef] [PubMed]

129. Leite, N.B.; Dos Santos Alvares, D.; De Souza, B.M.; Palma, M.S.; Ruggiero Neto, J. Effect of the aspartic acid D2 on the affinity of Polybia-MP1 to anionic lipid vesicles. Eur. Biophys. J. 2014, 43, 121-130. [CrossRef] [PubMed]

130. Leite, N.B.; Aufderhorst-Roberts, A.; Palma, M.S.; Connell, S.D.; Neto, J.R.; Beales, P.A. PE and PS Lipids Synergistically Enhance Membrane Poration by a Peptide with Anticancer Properties. Biophys. J. 2015, 109, 936-947. [CrossRef] [PubMed]

131. Xuan, H.L.; Duc, T.D.; Thuy, A.M.; Chau, P.M.; Tung, T.T. Chemical approaches in the development of natural nontoxic peptide Polybia-MP1 as a potential dual antimicrobial and antitumor agent. Amino Acids 2021, 53, 843-852. [CrossRef]

132. Alvares, D.S.; Ruggiero Neto, J.; Ambroggio, E.E. Phosphatidylserine lipids and membrane order precisely regulate the activity of Polybia-MP1 peptide. Biochim. Biophys. Acta-Biomembr. 2017, 1859, 1067-1074. [CrossRef] [PubMed]

133. Alvares, D.S.; Fanani, M.L.; Ruggiero Neto, J.; Wilke, N. The interfacial properties of the peptide Polybia-MP1 and its interaction with DPPC are modulated by lateral electrostatic attractions. Biochim. Biophys. Acta—Biomembr. 2016, 1858, 393-402. [CrossRef] [PubMed]

134. Alvares, D.S.; Wilke, N.; Ruggiero Neto, J.; Fanani, M.L. The insertion of Polybia-MP1 peptide into phospholipid monolayers is regulated by its anionic nature and phase state. Chem. Phys. Lipids 2017, 207, 38-48. [CrossRef] [PubMed]

135. Da Silva, A.M.B.; Silva-Gonçalves, L.C.; Oliveira, F.A.; Arcisio-Miranda, M. Pro-necrotic Activity of Cationic Mastoparan Peptides in Human Glioblastoma Multiforme Cells Via Membranolytic Action. Mol. Neurobiol. 2018, 55, 5490-5504. [CrossRef]

136. Takahashi, H.; Yumoto, K.; Yasuhara, K.; Nadres, E.T.; Kikuchi, Y.; Taichman, R.S.; Kuroda, K. Anticancer polymers designed for killing dormant prostate cancer cells. Sci. Rep. 2019, 9, 1096. [CrossRef] [PubMed]

137. Vernen, F.; Harvey, P.J.; Dias, S.A.; Veiga, A.S.; Huang, Y.H.; Craik, D.J.; Lawrence, N.; Henriques, S.T. Characterization of tachyplesin peptides and their cyclized analogues to improve antimicrobial and anticancer properties. Int. J. Mol. Sci. 2019, 20, 4184. [CrossRef]

138. Vernen, F.; Craik, D.J.; Lawrence, N.; Troeira Henriques, S. Cyclic Analogues of Horseshoe Crab Peptide Tachyplesin i with Anticancer and Cell Penetrating Properties. ACS Chem. Biol. 2019, 14, 2895-2908. [CrossRef]

139. Liu, C.; Qi, J.; Shan, B.; Ma, Y. Tachyplesin causes membrane instability that kills multidrug-resistant bacteria by inhibiting the 3-ketoacyl carrier protein reductase FabG. Front. Microbiol. 2018, 9, 825. [CrossRef]

140. Stec, B. Plant thionins-The structural perspective. Cell. Mol. Life Sci. 2006, 63, 1370-1385. [CrossRef]

141. Prabhu, S.; Dennison, S.R.; Lea, B.; Snape, T.J.; Nicholl, I.D.; Radecka, I.; Harris, F. Anionic Antimicrobial and Anticancer Peptides from Plants. CRC. Crit. Rev. Plant Sci. 2013, 32, 303-320. [CrossRef]

142. Gaspar, D.; Castanho, M.A.R.B. Anticancer peptides: Prospective innovation in cancer therapy. In Host Defense Peptides and Their Potential as Therapeutic Agents; Springer International Publishing: Cham, Switzerland, 2016; pp. 95-109, ISBN 9783319329499.

143. Patel, S.; Akhtar, N. Antimicrobial peptides (AMPs): The quintessential 'offense and defense' molecules are more than antimicrobials. Biomed. Pharmacother. 2017, 95, 1276-1283. [CrossRef] [PubMed]

144. Kaczanowski, S. Symbiotic Origin of Apoptosis. Results Probl. Cell Differ. 2020, 69, 253-280. [CrossRef] [PubMed]

145. Min, K.A.; Maharjan, P.; Ham, S.; Shin, M.C. Pro-apoptotic peptides-based cancer therapies: Challenges and strategies to enhance therapeutic efficacy. Arch. Pharm. Res. 2018, 41, 594-616. [CrossRef]

146. Xia, L.J.; Wu, Y.L.; Ma, J.; Zhang, F.C. Therapeutic effects of antimicrobial peptide on malignant ascites in a mouse model. Mol. Med. Rep. 2018, 17, 6245-6252. [CrossRef] [PubMed]

147. Mandal, S.M.; Migliolo, L.; Das, S.; Mandal, M.; Franco, O.L.; Hazra, T.K. Identification and characterization of a bactericidal and proapoptotic peptide from cycas revoluta seeds with DNA binding properties. J. Cell. Biochem. 2012, 113, 184-193. [CrossRef]

148. Trindade, F.; Amado, F.; Pinto da Costa, J.; Ferreira, R.; Maia, C.; Henriques, I.; Colaço, B.; Vitorino, R. Salivary peptidomic as a tool to disclose new potential antimicrobial peptides. J. Proteomics 2015, 115, 49-57. [CrossRef]

149. Azuma, M.; Del Carpio, C.A.; Kojima, T.; Yokoyama, I.; Tajiri, H.; Yoshikawa, K.; Saga, S. Antibacterial activity of multiple antigen peptides homologous to a loop region in human lactoferrin. J. Pept. Res. 2008, 54, 237-241. [CrossRef]

150. Anunthawan, T.; Yaraksa, N.; Phosri, S.; Theansungnoen, T.; Daduang, S.; Dhiravisit, A.; Thammasirirak, S. Improving the antibacterial activity and selectivity of an ultra short peptide by hydrophobic and hydrophilic amino acid stretches. Bioorg. Med. Chem. Lett. 2013, 23, 4657-4662. [CrossRef]

151. Okumura, K.; Itoh, A.; Isogai, E.; Hirose, K.; Hosokawa, Y.; Abiko, Y.; Shibata, T.; Hirata, M.; Isogai, H. C-terminal domain of human CAP18 antimicrobial peptide induces apoptosis in oral squamous cell carcinoma SAS-H1 cells. Cancer Lett. 2004, 212, 185-194. [CrossRef]

152. Ren, S.X.; Shen, J.; Cheng, A.S.L.; Lu, L.; Chan, R.L.Y.; Li, Z.J.; Wang, X.J.; Wong, C.C.M.; Zhang, L.; Ng, S.S.M.; et al. FK-16 Derived from the Anticancer Peptide LL-37 Induces Caspase-Independent Apoptosis and Autophagic Cell Death in Colon Cancer Cells. PLoS ONE 2013, 8, e063641. [CrossRef]

153. Shai, Y.; Bach, D.; Yanovsky, A. Channel formation properties of synthetic pardaxin and analogues. J. Biol. Chem. 1990, 265, 20202-20209. [CrossRef]

154. Xia, L.; Wu, Y.; Ma, J.; Yang, J.; Zhang, F. The antibacterial peptide from Bombyx mori cecropinXJ induced growth arrest and apoptosis in human hepatocellular carcinoma cells. Oncol. Lett. 2016, 12, 57-62. [CrossRef] 
155. Ramos-Martín, F.; D'Amelio, N. Molecular basis of the anticancer and antibacterial properties of cecropinxj peptide: An in silico study. Int. J. Mol. Sci. 2021, 22, 691. [CrossRef]

156. Chang, V.H.S.; Yang, D.H.A.; Lin, H.H.; Pearce, G.; Ryan, C.A.; Chen, Y.C. IbACP, a sixteen-amino-acid peptide isolated from Ipomoea batatas leaves, induces carcinoma cell apoptosis. Peptides 2013, 47, 148-156. [CrossRef] [PubMed]

157. Yokoyama, S.; Kato, K.; Koba, A.; Minami, Y.; Watanabe, K.; Yagi, F. Purification, characterization, and sequencing of antimicrobial peptides, Cy-AMP1, Cy-AMP2, and Cy-AMP3, from the Cycad (Cycas revoluta) seeds. Peptides 2008, 29, 2110-2117. [CrossRef]

158. Barbosa Pelegrini, P.; Del Sarto, R.P.; Silva, O.N.; Franco, O.L.; Grossi-De-Sa, M.F. Antibacterial peptides from plants: What they are and how they probably work. Biochem. Res. Int. 2011, 2011, 250349. [CrossRef]

159. Dijk, I.A.; Laura Ferrando, M.; Wijk, A.; Hoebe, R.A.; Nazmi, K.; Jonge, W.J.; Krawczyk, P.M.; Bolscher, J.G.M.; Veerman, E.C.I.; Stap, J. Human salivary peptide histatin-1 stimulates epithelial and endothelial cell adhesion and barrier function. FASEB J. 2017, 31, 3922-3933. [CrossRef]

160. Grant, M.; Kilsgård, O.; Åkerman, S.; Klinge, B.; Demmer, R.T.; Malmström, J.; Jönsson, D. The Human Salivary Antimicrobial Peptide Profile according to the Oral Microbiota in Health, Periodontitis and Smoking. J. Innate Immun. 2019, 11, 432-444. [CrossRef]

161. Da Costa, J.P.; Carvalhais, V.; Amado, F.; Silva, A.; Nogueira-Ferreira, R.; Ferreira, R.; Helguero, L.; Vitorino, R. Anti-tumoral activity of human salivary peptides. Peptides 2015, 71, 170-178. [CrossRef]

162. Vila, T.; Rizk, A.M.; Sultan, A.S.; Jabra-Rizk, M.A. The power of saliva: Antimicrobial and beyond. PLoS Pathog. 2019, 15, e1008058. [CrossRef]

163. Morici, P.; Florio, W.; Rizzato, C.; Ghelardi, E.; Tavanti, A.; Rossolini, G.M.; Lupetti, A. Synergistic activity of synthetic N-terminal peptide of human lactoferrin in combination with various antibiotics against carbapenem-resistant Klebsiella pneumoniae strains. Eur. J. Clin. Microbiol. Infect. Dis. 2017, 36, 1739-1748. [CrossRef]

164. Zweytick, D.; Pabst, G.; Abuja, P.M.; Jilek, A.; Blondelle, S.E.; Andrä, J.; Jerala, R.; Monreal, D.; Martinez de Tejada, G.; Lohner, K. Influence of $\mathrm{N}$-acylation of a peptide derived from human lactoferricin on membrane selectivity. Biochim. Biophys. Acta-Biomembr. 2006, 1758, 1426-1435. [CrossRef] [PubMed]

165. Iglesias-Figueroa, B.F.; Siqueiros-Cendón, T.S.; Gutierrez, D.A.; Aguilera, R.J.; Espinoza-Sánchez, E.A.; Arévalo-Gallegos, S.; Varela-Ramirez, A.; Rascón-Cruz, Q. Recombinant human lactoferrin induces apoptosis, disruption of F-actin structure and cell cycle arrest with selective cytotoxicity on human triple negative breast cancer cells. Apoptosis 2019, 24, 562-577. [CrossRef] [PubMed]

166. Riedl, S.; Rinner, B.; Schaider, H.; Lohner, K.; Zweytick, D. Killing of melanoma cells and their metastases by human lactoferricin derivatives requires interaction with the cancer marker phosphatidylserine. BioMetals 2014, 27, 981-997. [CrossRef] [PubMed]

167. Rascón-Cruz, Q.; Espinoza-Sánchez, E.A.; Siqueiros-Cendón, T.S.; Nakamura-Bencomo, S.I.; Arévalo-Gallegos, S.; IglesiasFigueroa, B.F. Lactoferrin: A glycoprotein involved in immunomodulation, anticancer, and antimicrobial processes. Molecules 2021, 26, 205. [CrossRef]

168. Pata, S.; Yaraksa, N.; Daduang, S.; Temsiripong, Y.; Svasti, J.; Araki, T.; Thammasirirak, S. Characterization of the novel antibacterial peptide Leucrocin from crocodile (Crocodylus siamensis) white blood cell extracts. Dev. Comp. Immunol. 2011, 35, 545-553. [CrossRef]

169. Theansungnoen, T.; Maijaroen, S.; Jangpromma, N.; Yaraksa, N.; Daduang, S.; Temsiripong, T.; Daduang, J.; Klaynongsruang, S. Cationic Antimicrobial Peptides Derived from Crocodylus siamensis Leukocyte Extract, Revealing Anticancer Activity and Apoptotic Induction on Human Cervical Cancer Cells. Protein J. 2016, 35, 202-211. [CrossRef]

170. Patathananone, S.; Thammasirirak, S.; Daduang, J.; Chung, J.G.; Temsiripong, Y.; Daduang, S. Bioactive compounds from crocodile (Crocodylus siamensis ) white blood cells induced apoptotic cell death in hela cells. Environ. Toxicol. 2016, 31, 986-997. [CrossRef]

171. Maijaroen, S.; Jangpromma, N.; Daduang, J.; Klaynongsruang, S. KT2 and RT2 modified antimicrobial peptides derived from Crocodylus siamensis Leucrocin I show activity against human colon cancer HCT-116 cells. Environ. Toxicol. Pharmacol. 2018, 62, 164-176. [CrossRef] [PubMed]

172. Yang, B.; Good, D.; Mosaiab, T.; Liu, W.; Ni, G.; Kaur, J.; Liu, X.; Jessop, C.; Yang, L.; Fadhil, R.; et al. Significance of LL-37 on Immunomodulation and Disease Outcome. Biomed Res. Int. 2020, 2020, 8349712. [CrossRef]

173. Wang, G.; Narayana, J.L.; Mishra, B.; Zhang, Y.; Wang, F.; Wang, C.; Zarena, D.; Lushnikova, T.; Wang, X. Design of Antimicrobial Peptides: Progress Made with Human Cathelicidin LL-37. In Antimicrobial Peptides. Advances in Experimental Medicine and Biology; Matsuzaki, K., Ed.; Springer: Singapore, 2019; Volume 1117, pp. 215-240.

174. Kuroda, K.; Okumura, K.; Isogai, H.; Isogai, E. The Human Cathelicidin Antimicrobial Peptide LL-37 and Mimics are Potential Anticancer Drugs. Front. Oncol. 2015, 5, 144. [CrossRef]

175. Hsu, W.H.; Lai, Y.J.; Wu, S.C. Effects of the anti-microbial peptide pardaxin plus sodium erythorbate dissolved in different gels on the quality of Pacific white shrimp under refrigerated storage. Food Control 2017, 73, 712-719. [CrossRef]

176. Bhunia, A.; Domadia, P.N.; Torres, J.; Hallock, K.J.; Ramamoorthy, A.; Bhattacharjya, S. NMR structure of pardaxin, a pore-forming antimicrobial peptide, in lipopolysaccharide micelles: Mechanism of outer membrane permeabilization. J. Biol. Chem. 2010, 285, 3883-3895. [CrossRef]

177. Epand, R.F.; Ramamoorthy, A.; Epand, R.M. Membrane Lipid Composition and the Interaction of Pardaxin: The Role of Cholesterol. Protein Pept. Lett. 2005, 13, 1-5. [CrossRef] 
178. Ting, C.H.; Huang, H.N.; Huang, T.C.; Wu, C.J.; Chen, J.Y. The mechanisms by which pardaxin, a natural cationic antimicrobial peptide, targets the endoplasmic reticulum and induces c-FOS. Biomaterials 2014, 35, 3627-3640. [CrossRef]

179. Wu, S.-P.; Huang, T.-C.; Lin, C.-C.; Hui, C.-F.; Lin, C.-H.; Chen, J.-Y. Pardaxin, a Fish Antimicrobial Peptide, Exhibits Antitumor Activity toward Murine Fibrosarcoma in vitro and In vivo. Mar. Drugs 2012, 10, 1852-1872. [CrossRef] [PubMed]

180. Huang, T.C.; Lee, J.F.; Chen, J.Y. Pardaxin, an antimicrobial peptide, triggers caspase-dependent and ROS-mediated apoptosis in HT-1080 cells. Mar. Drugs 2011, 9, 1995-2009. [CrossRef] [PubMed]

181. Bhandari, D.; Rafiq, S.; Gat, Y.; Gat, P.; Waghmare, R.; Kumar, V. A Review on Bioactive Peptides: Physiological Functions, Bioavailability and Safety. Int. J. Pept. Res. Ther. 2020, 26. [CrossRef]

182. Parvy, J.P.; Yu, Y.; Dostalova, A.; Kondo, S.; Kurjan, A.; Bulet, P.; Lemaître, B.; Vidal, M.; Cordero, J.B. The antimicrobial peptide defensin cooperates with tumour necrosis factor to drive tumour cell death in Drosophila. eLife 2019, 8, e45061. [CrossRef]

183. Avilés-Gaxiola, S.; Gutiérrez-Grijalva, E.P.; León-Felix, J.; Angulo-Escalante, M.A.; Heredia, J.B. Peptides in Colorectal Cancer: Current State of Knowledge. Plant Foods Hum. Nutr. 2020, 75, 467-476. [CrossRef] [PubMed]

184. Ashaolu, T.J. Health Applications of Soy Protein Hydrolysates. Int. J. Pept. Res. Ther. 2020, 26, 2333-2343. [CrossRef]

185. Wan, X.; Liu, H.; Sun, Y.; Zhang, J.; Chen, X.; Chen, N. Lunasin: A promising polypeptide for the prevention and treatment of cancer. Oncol. Lett. 2017, 13, 3997-4001. [CrossRef] [PubMed]

186. Galvez, A.F.; Chen, N.; Macasieb, J.; De Lumen, B.O. Chemopreventive property of a soybean peptide (Lunasin) that binds to deacetylated histones and inhibits acetylation. Cancer Res. 2001, 61, 7473-7478. [PubMed]

187. Marcela, G.-M. Bioactive Peptides from Legumes as Anticancer Therapeutic Agents. Int. J. Cancer Clin. Res. 2017, 4, 81. [CrossRef]

188. Rusdi, N.K.; Purwaningsih, E.H.; Hestiantoro, A.; Elya, B.; Kusmardi, K. In vivo antimammary tumor effects of soybean extract with targeted lunasin (ET-Lun). Pharmacogn. J. 2021, 13, 1269-1276. [CrossRef]

189. Khalifa, S.A.M.; Elias, N.; Farag, M.A.; Chen, L.; Saeed, A.; Hegazy, M.E.F.; Moustafa, M.S.; El-Wahed, A.A.; Al-Mousawi, S.M.; Musharraf, S.G.; et al. Marine natural products: A source of novel anticancer drugs. Mar. Drugs 2019, 17, 491. [CrossRef]

190. Görgüç, A.; Gençdă̆, E.; Yılmaz, F.M. Bioactive peptides derived from plant origin by-products: Biological activities and techno-functional utilizations in food developments-A review. Food Res. Int. 2020, 136, 109504. [CrossRef] [PubMed]

191. Jiang, H.; Feng, J.; Du, Z.; Zhen, H.; Lin, M.; Jia, S.; Li, T.; Huang, X.; Ostenson, C.G.; Chen, Z. Oral administration of soybean peptide Vglycin normalizes fasting glucose and restores impaired pancreatic function in Type 2 diabetic Wistar rats. J. Nutr. Biochem. 2014, 25, 954-963. [CrossRef]

192. Gao, C.; Sun, R.; Xie, Y.R.; Jiang, A.L.; Lin, M.; Li, M.; Chen, Z.W.; Zhang, P.; Jin, H.; Feng, J.P. The soy-derived peptide Vglycin inhibits the growth of colon cancer cells in vitro and in vivo. Exp. Biol. Med. 2017, 242, 1034-1043. [CrossRef] [PubMed]

193. Abbasi Gharibkandi, N.; Conlon, J.M.; Hosseinimehr, S.J. Strategies for improving stability and pharmacokinetic characteristics of radiolabeled peptides for imaging and therapy. Peptides 2020, 133, 170385. [CrossRef]

194. Sathya, R.; Mubarakali, D.; Mohamedsaalis, J.; Kim, J.W. A systemic review on microalgal peptides: Bioprocess and sustainable applications. Sustainability 2021, 13, 3262. [CrossRef]

195. Luong, H.X.; Thanh, T.T.; Tran, T.H. Antimicrobial peptides-Advances in development of therapeutic applications. Life Sci. 2020, 260, 118407. [CrossRef]

196. Kumar, P.; Kizhakkedathu, J.N.; Straus, S.K. Antimicrobial peptides: Diversity, mechanism of action and strategies to improve the activity and biocompatibility in vivo. Biomolecules 2018, 8, 4. [CrossRef] [PubMed]

197. Mathur, D.; Singh, S.; Mehta, A.; Agrawal, P.; Raghava, G.P.S. In silico approaches for predicting the half-life of natural and modified peptides in blood. PLoS ONE 2018, 13, e0196829. [CrossRef] [PubMed]

198. Pilleron, S.; Sarfati, D.; Janssen-Heijnen, M.; Vignat, J.; Ferlay, J.; Bray, F.; Soerjomataram, I. Global cancer incidence in older adults, 2012 and 2035: A population-based study. Int. J. Cancer 2019, 144, 49-58. [CrossRef]

199. Tripathi, P.P.; Arami, H.; Banga, I.; Gupta, J.; Gandhi, S. Cell penetrating peptides in preclinical and clinical cancer diagnosis and therapy. Oncotarget 2018, 9, 37252. [CrossRef]

200. Zafar, S.; Beg, S.; Panda, S.K.; Rahman, M.; Alharbi, K.S.; Jain, G.K.; Ahmad, F.J. Novel therapeutic interventions in cancer treatment using protein and peptide-based targeted smart systems. Semin. Cancer Biol. 2021, 69, 249-267. [CrossRef] [PubMed]

201. Sang, M.; Zhang, J.; Zhuge, Q. Selective cytotoxicity of the antibacterial peptide ABP-dHC-Cecropin A and its analog towards leukemia cells. Eur. J. Pharmacol. 2017, 803, 138-147. [CrossRef] [PubMed]

202. Lin, Y.C.; Lim, Y.F.; Russo, E.; Schneider, P.; Bolliger, L.; Edenharter, A.; Altmann, K.H.; Halin, C.; Hiss, J.A.; Schneider, G. Multidimensional Design of Anticancer Peptides. Angew. Chem. Int. Ed. 2015, 35, 10370-10374. [CrossRef] [PubMed]

203. Trinidad-Calderón, P.A.; Acosta-Cruz, E.; Rivero-Masante, M.N.; Díaz-Gómez, J.L.; García-Lara, S.; López-Castillo, L.M. Maize bioactive peptides: From structure to human health. J. Cereal Sci. 2021, 100, 103232. [CrossRef]

204. Robey, R.W.; Pluchino, K.M.; Hall, M.D.; Fojo, A.T.; Bates, S.E.; Gottesman, M.M. Revisiting the role of ABC transporters in multidrug-resistant cancer. Nat. Rev. Cancer 2018, 18, 452-464. [CrossRef] [PubMed]

205. Li, X.; Gohain, N.; Chen, S.; Li, Y.; Zhao, X.; Li, B.; Tolbert, W.D.; He, W.; Pazgier, M.; Hu, H.; et al. Design of ultrahigh-affinity and dual-specificity peptide antagonists of MDM2 and MDMX for P53 activation and tumor suppression. Acta Pharm. Sin. B 2021, 11, 2655-2669. [CrossRef] [PubMed] 
206. Zhao, H.; Qin, X.; Yang, D.; Jiang, Y.; Zheng, W.; Wang, D.; Tian, Y.; Liu, Q.; Xu, N.; Li, Z. The development of activatable lytic peptides for targeting triple negative breast cancer. Cell Death Discov. 2017, 3, 17037. [CrossRef] [PubMed]

207. Khine, H.E.E.; Ecoy, G.A.U.; Roytrakul, S.; Phaonakrop, N.; Pornputtapong, N.; Prompetchara, E.; Chanvorachote, P.; Chaotham, C. Chemosensitizing activity of peptide from Lentinus squarrosulus (Mont.) on cisplatin-induced apoptosis in human lung cancer cells. Sci. Rep. 2021, 11, 4060. [CrossRef] 